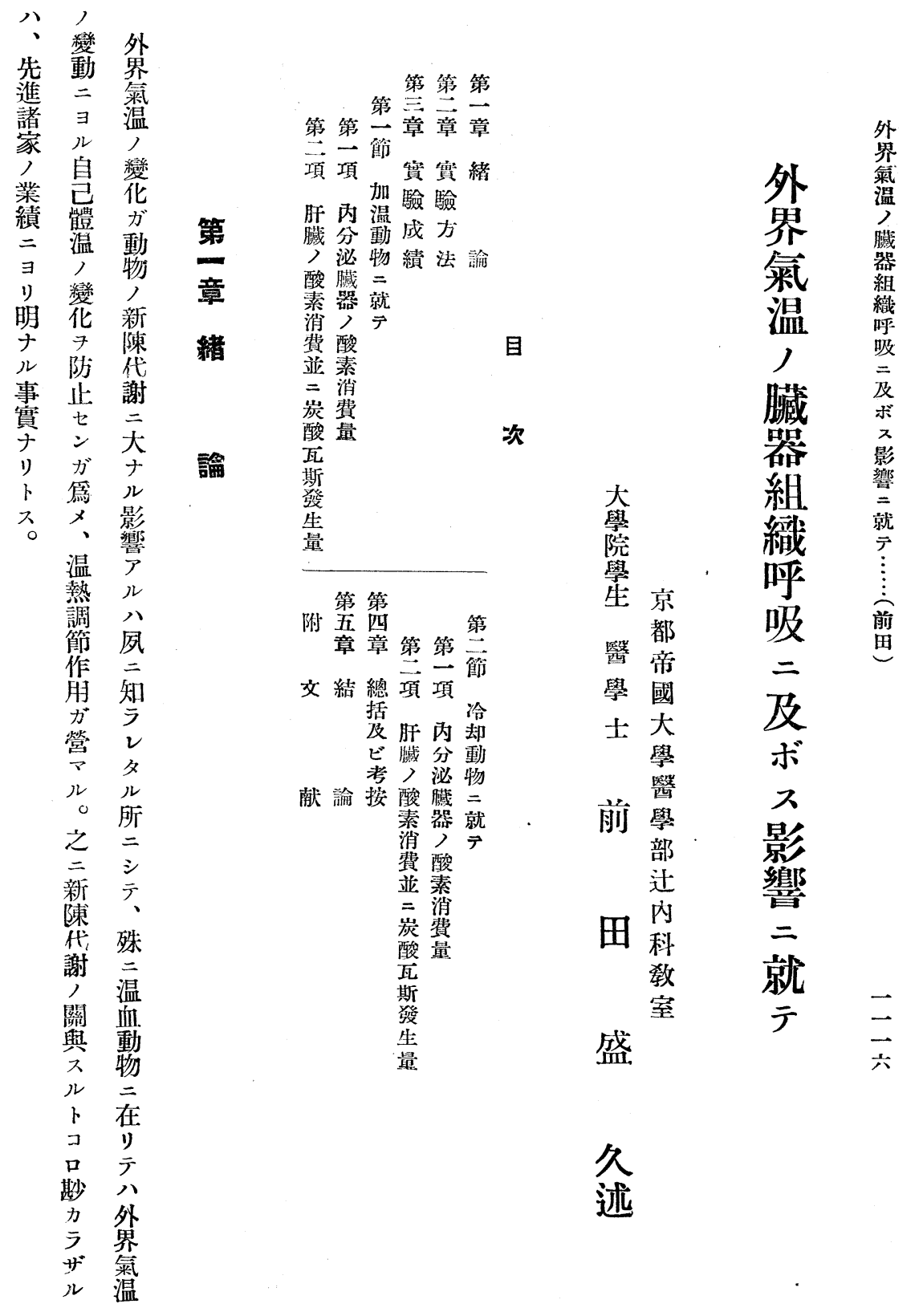




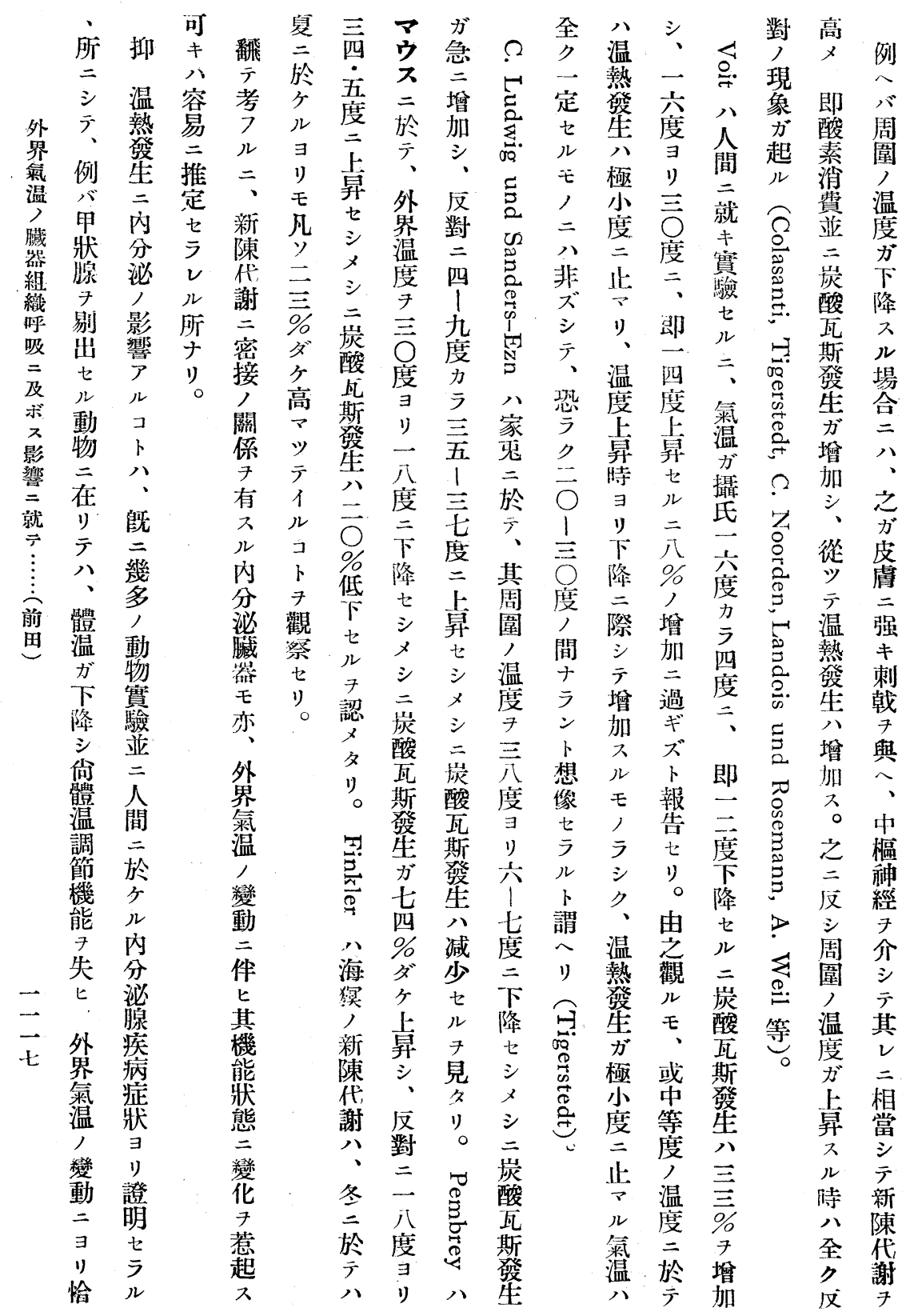




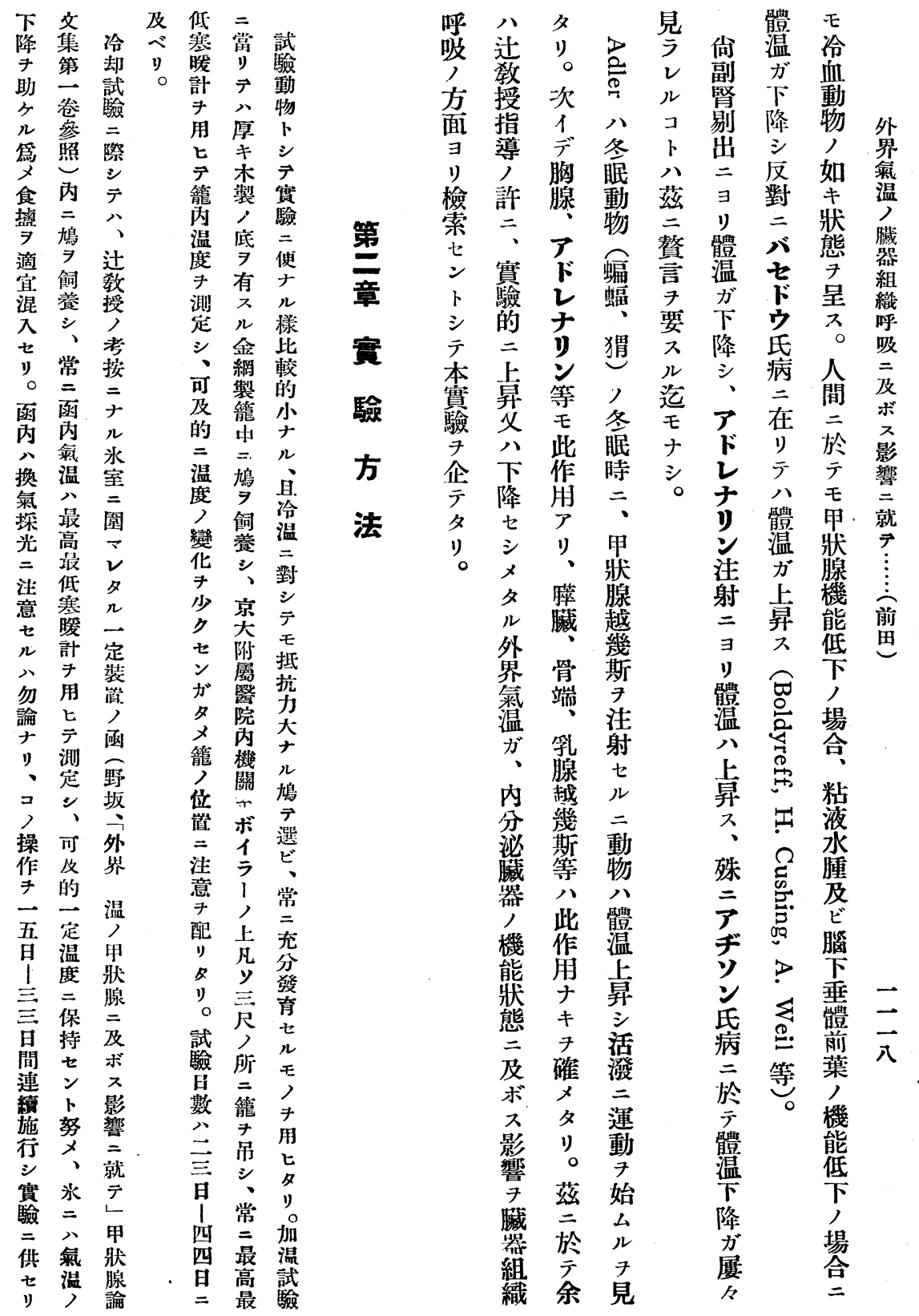




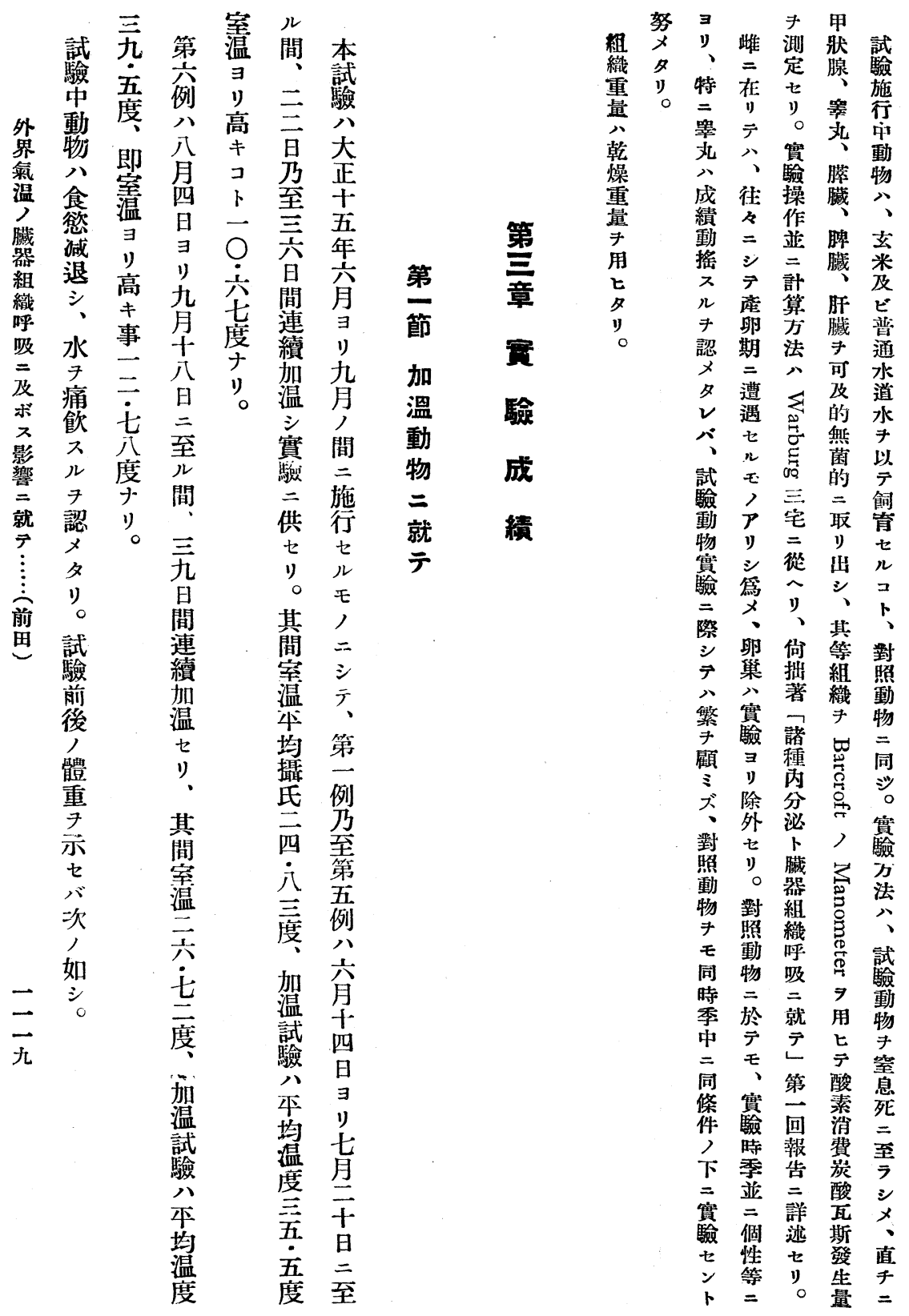



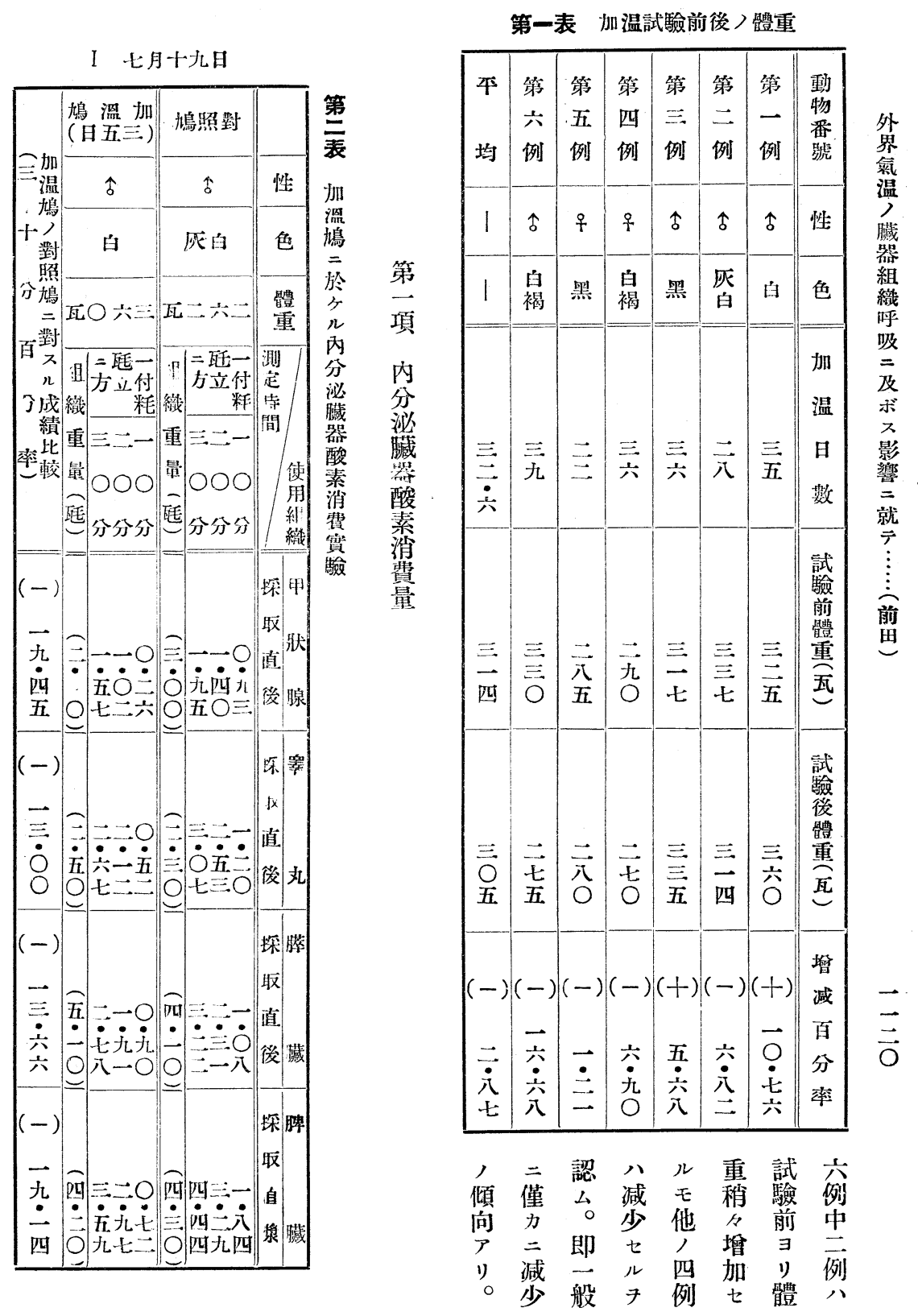
III 七月二十日

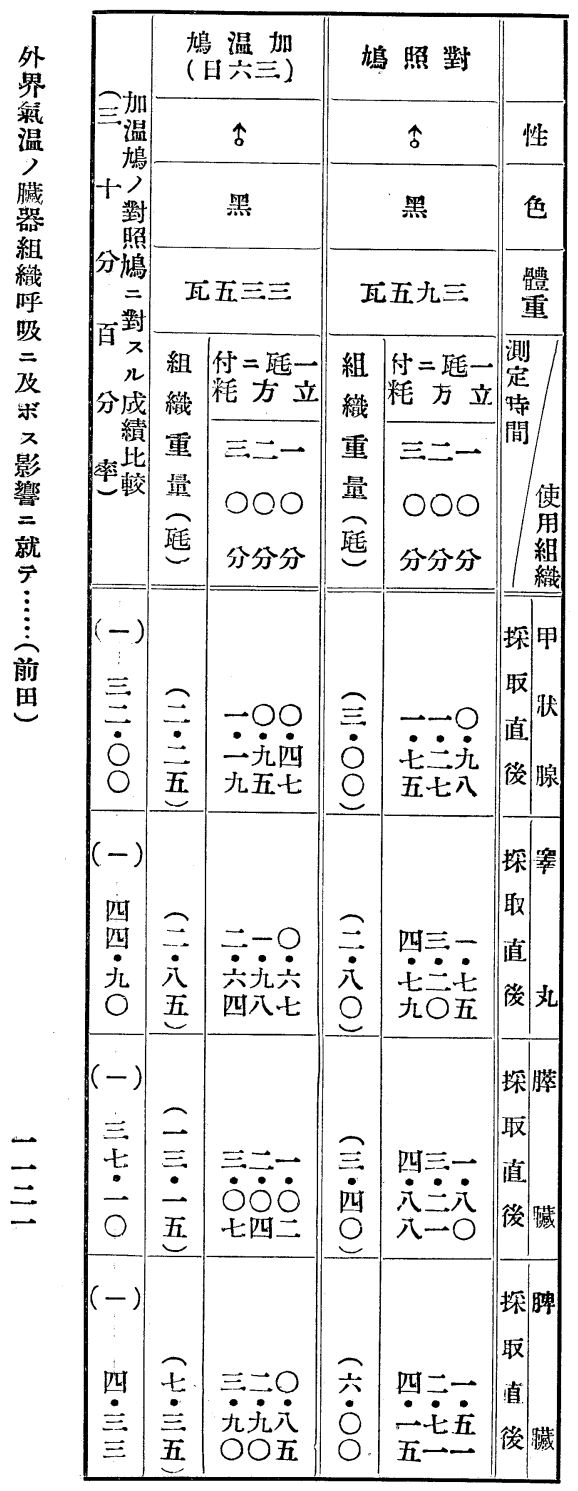

II七月十九日

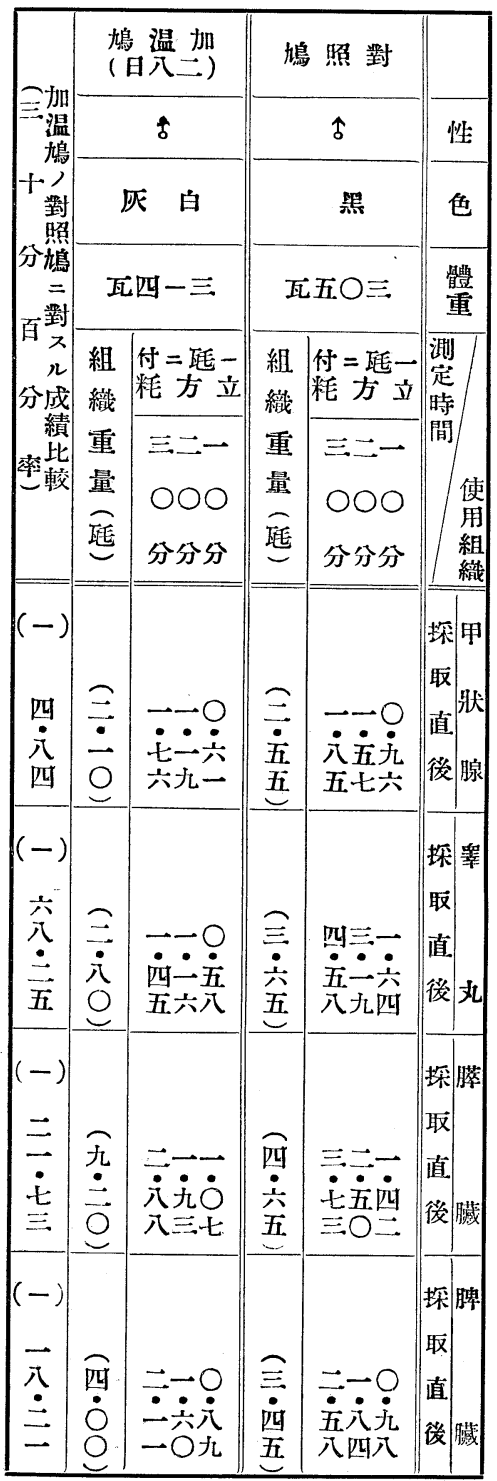


V 七月二十一日

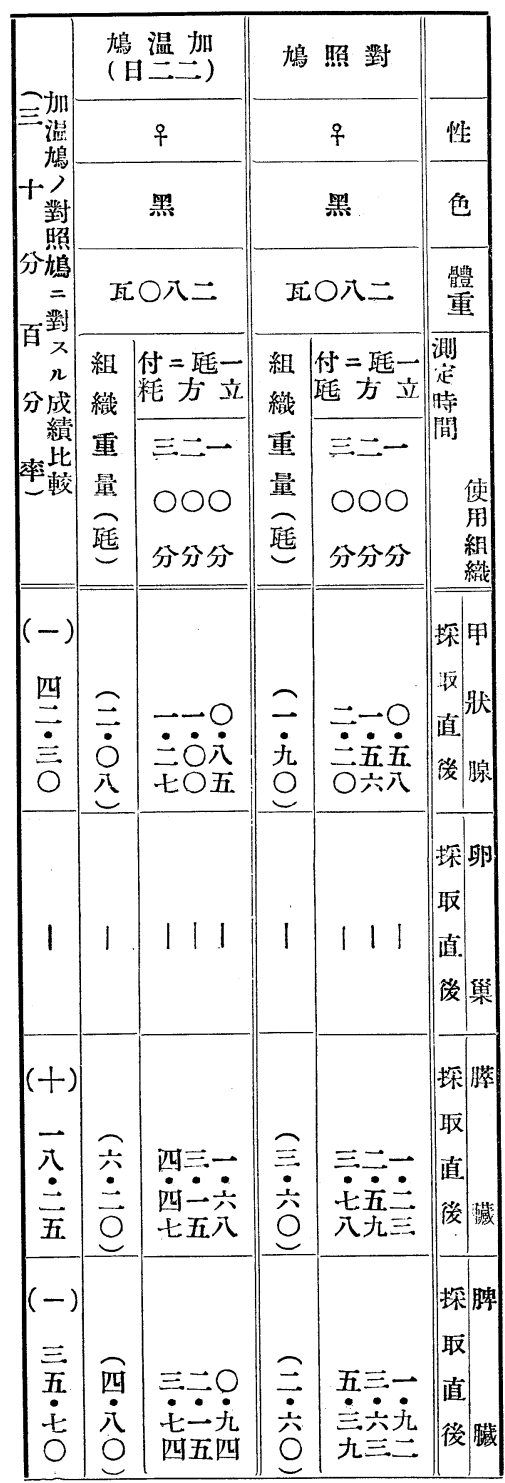

IV $上$ 月二十日

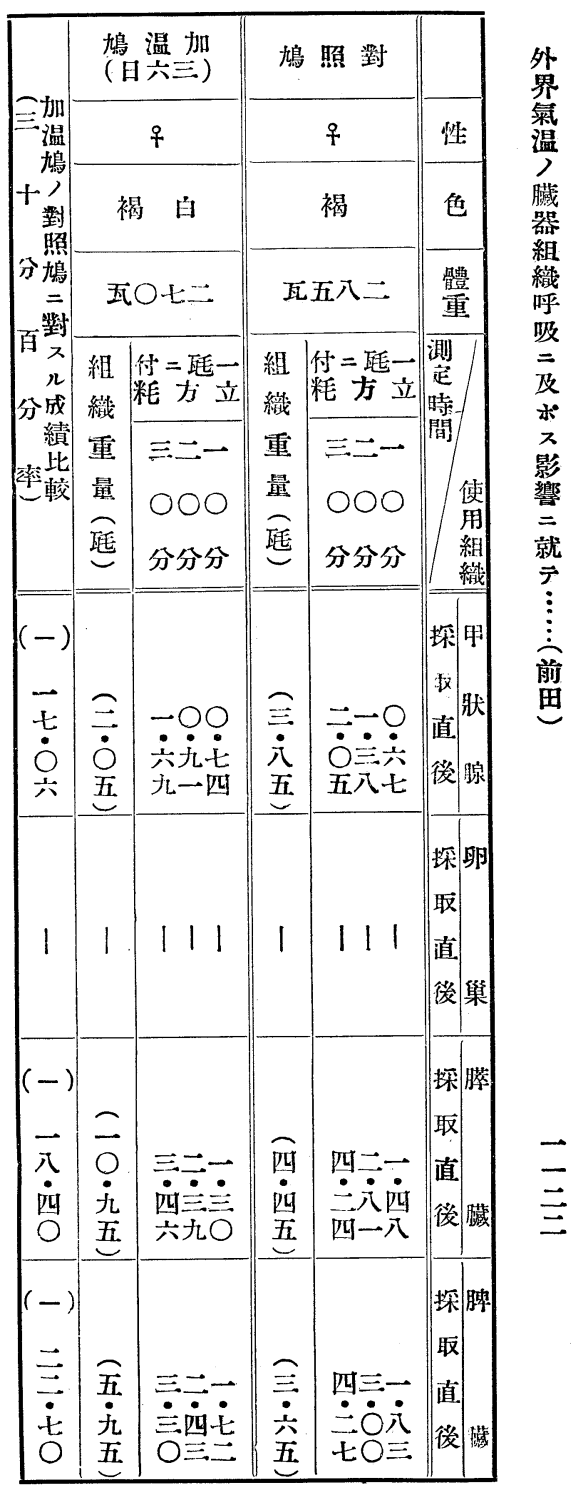




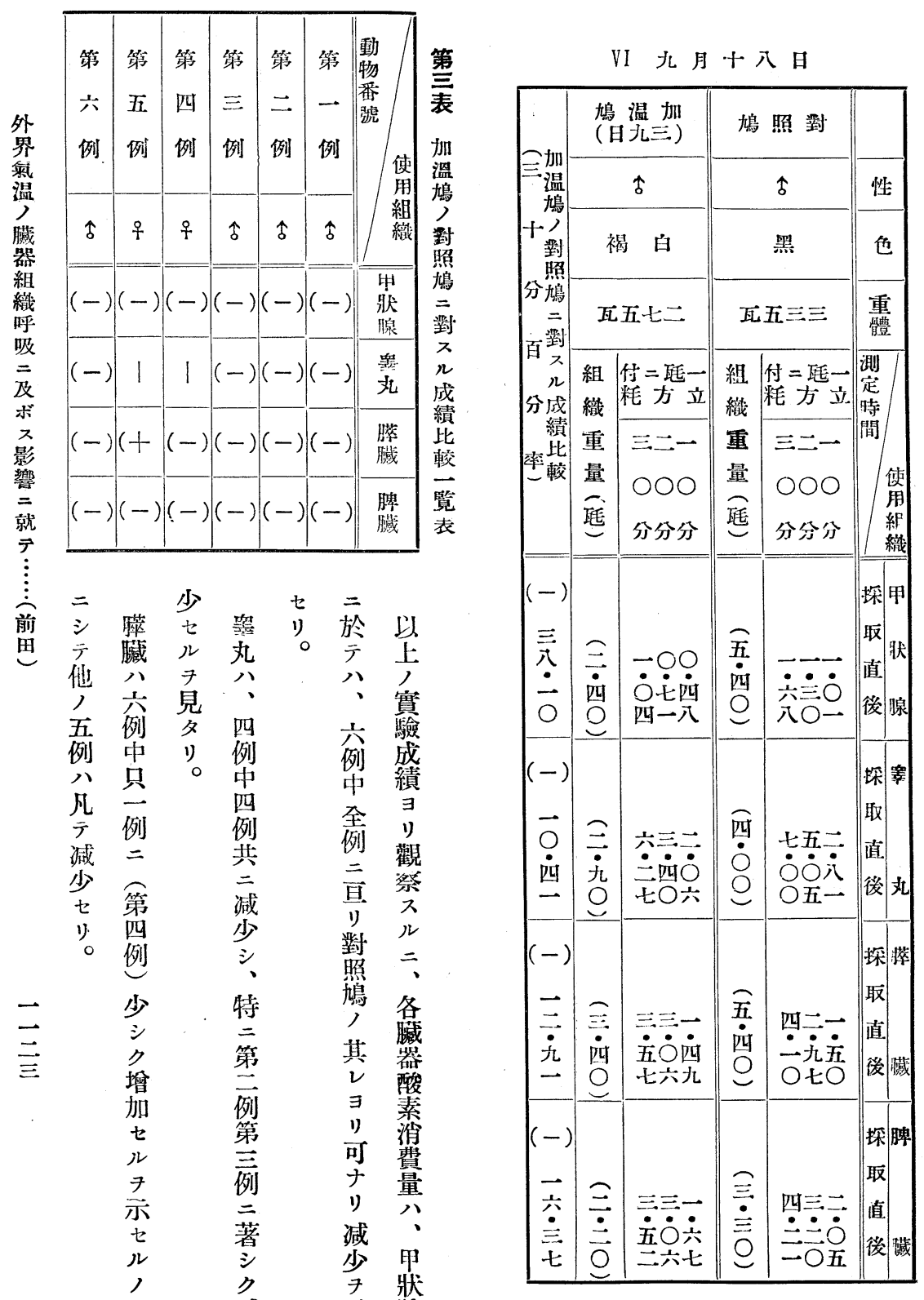



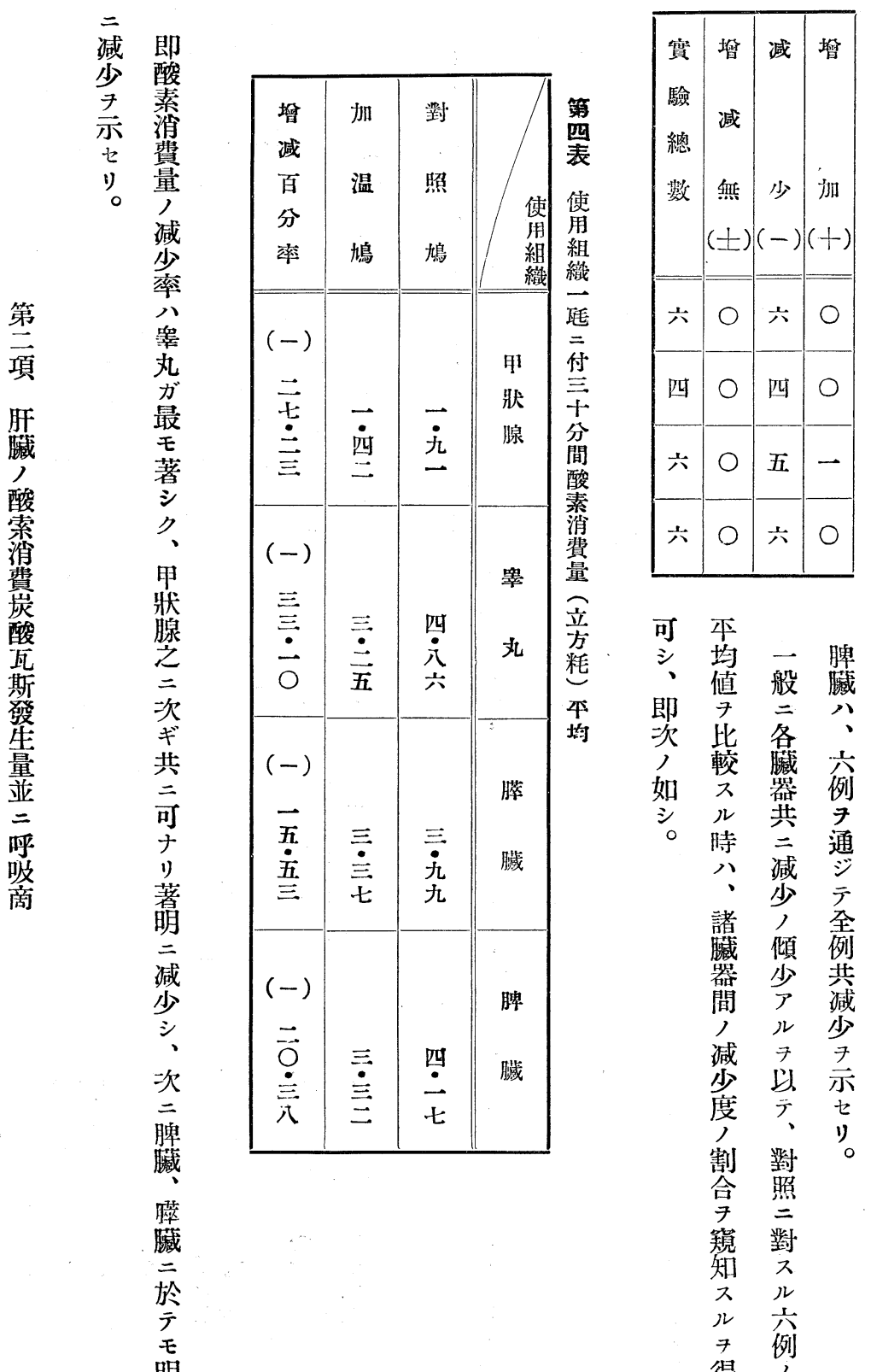

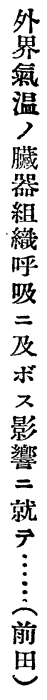

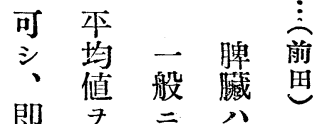

即光比各?

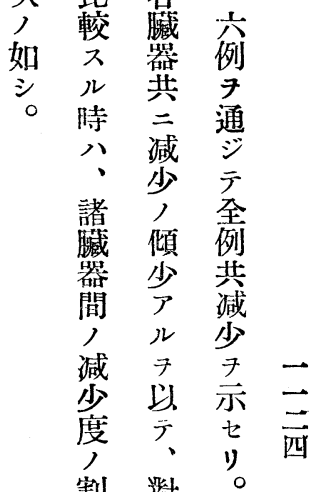

割 對

合 照

筧對

知

ス

得 例 


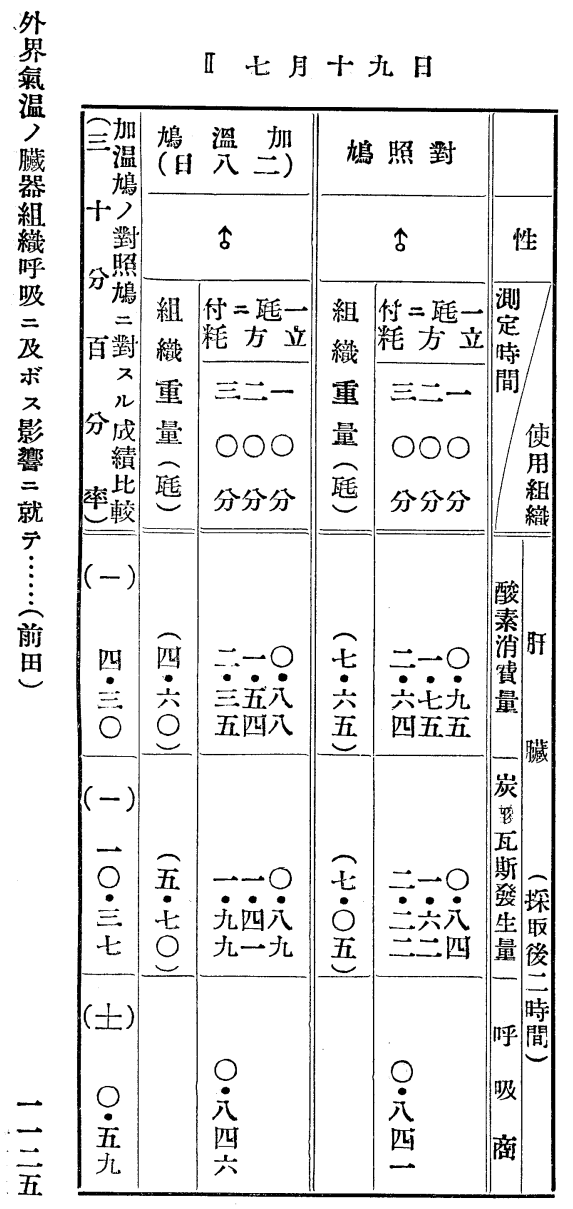

I七月十九日

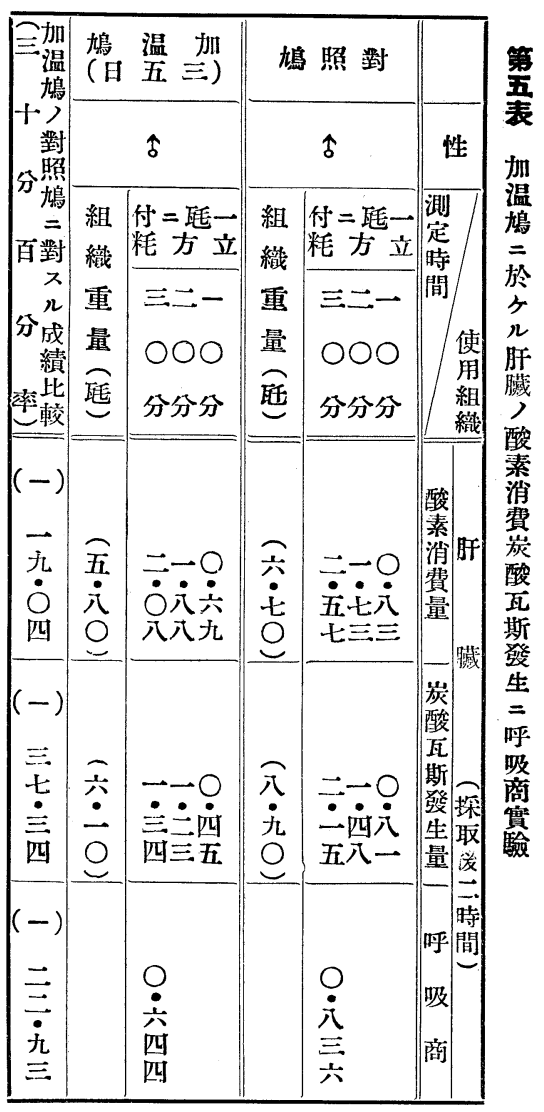


IV 七月二十 二日

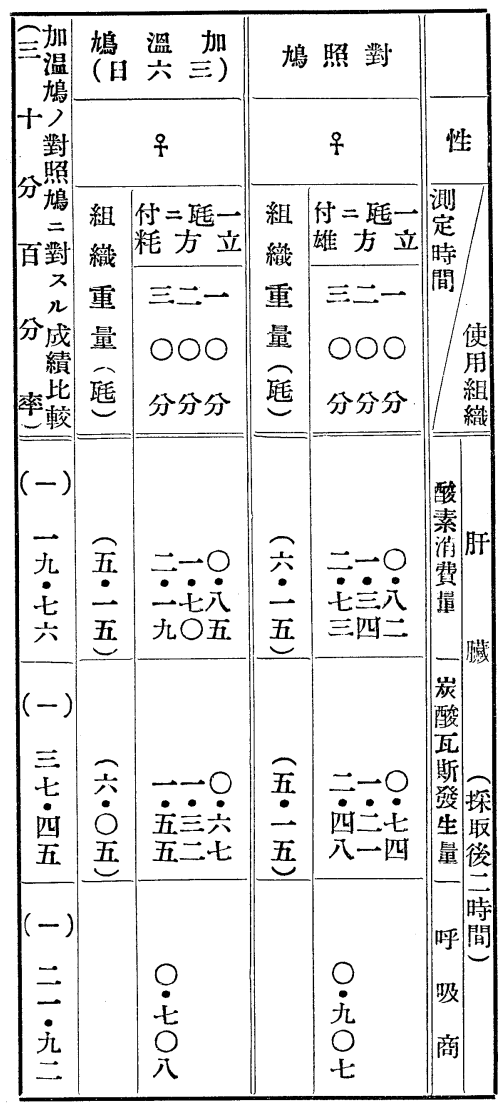

III 月二

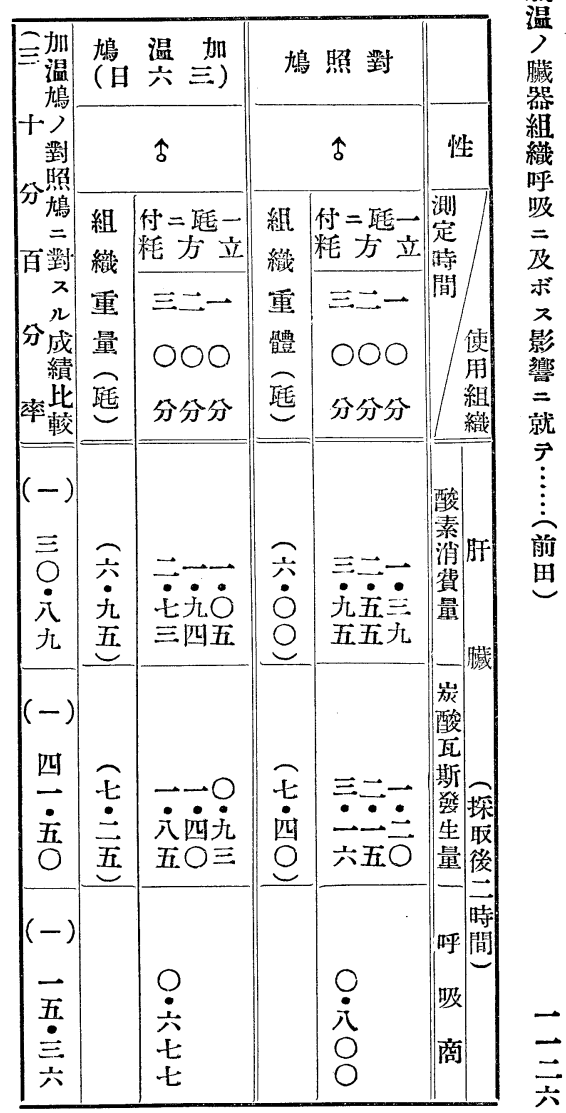




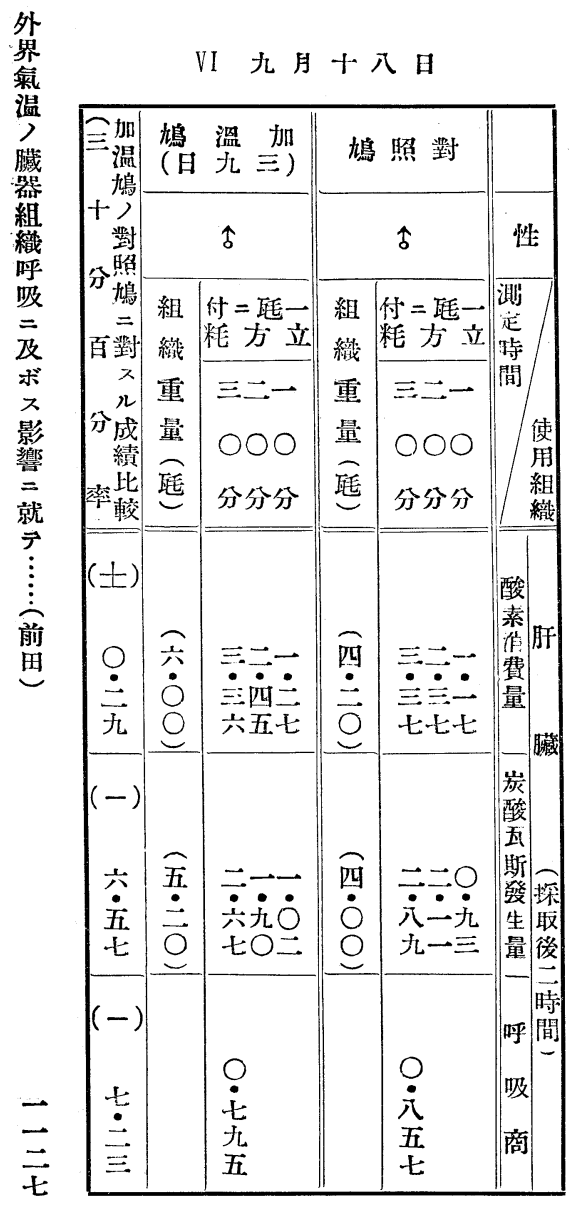

V七月二十一日

\begin{tabular}{|c|c|c|c|c|c|}
\hline 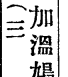 & 鳩 & 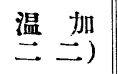 & & 照 對 & \\
\hline 對 & & q. & & qq & 性 \\
\hline 䲧 & 組 & $\begin{array}{l}\text { 付=琵一 } \\
\text { 粍 立 }\end{array}$ & 組 & 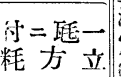 & 玮 \\
\hline 자 & 重 & $\equiv \rightarrow-$ & 重 & $\equiv-$ & 閒 \\
\hline 分成 & 量 & 000 & 量 & 000 & 使 \\
\hline 率些较 & 琶 & 分分分 & 琶 & 分分分 & $\begin{array}{l}\text { 組 } \\
\text { 緎 }\end{array}$ \\
\hline$(-)$ & & & & & th \\
\hline$=$ & 毛 & $\equiv$ 二- & 分 & E- & 粦肝 \\
\hline$\dot{0}$ & 亲 & $\dot{\mathrm{E}}$-五 & $\doteqdot$ & 元六立 & 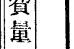 \\
\hline 九 & O & 四六四 & O & & 歲 \\
\hline$(+)$ & & & & & 炭 \\
\hline 三 & I & & $\widehat{\pi}$ & & 斯 \\
\hline $\overrightarrow{\dot{\alpha i}}$ & 公 & 立主 & $\stackrel{\circ}{\doteq}$ & 穴立 & 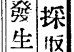 \\
\hline 宎 & 0 & $\vec{\lambda} 七 \overrightarrow{0}$ & O & 九九六 & 量後 \\
\hline$(+)$ & & & & & 呼间間 \\
\hline 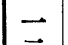 & & ? & & $?$ & 吸 \\
\hline$\dot{0}$ & & $\begin{array}{l}\lambda \\
t\end{array}$ & & 芫 & \\
\hline 0 & & t & & $\Xi$ & \\
\hline
\end{tabular}



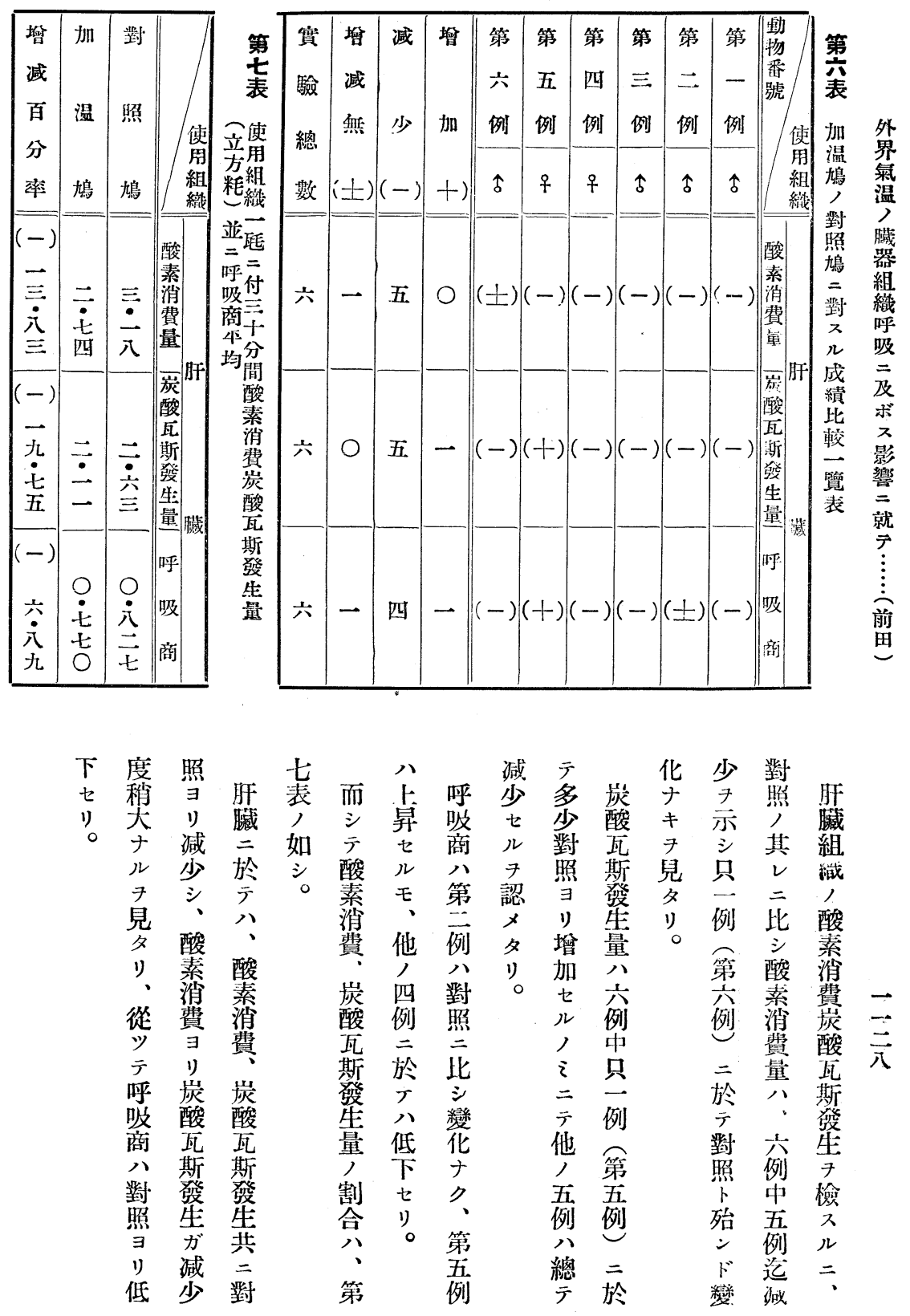


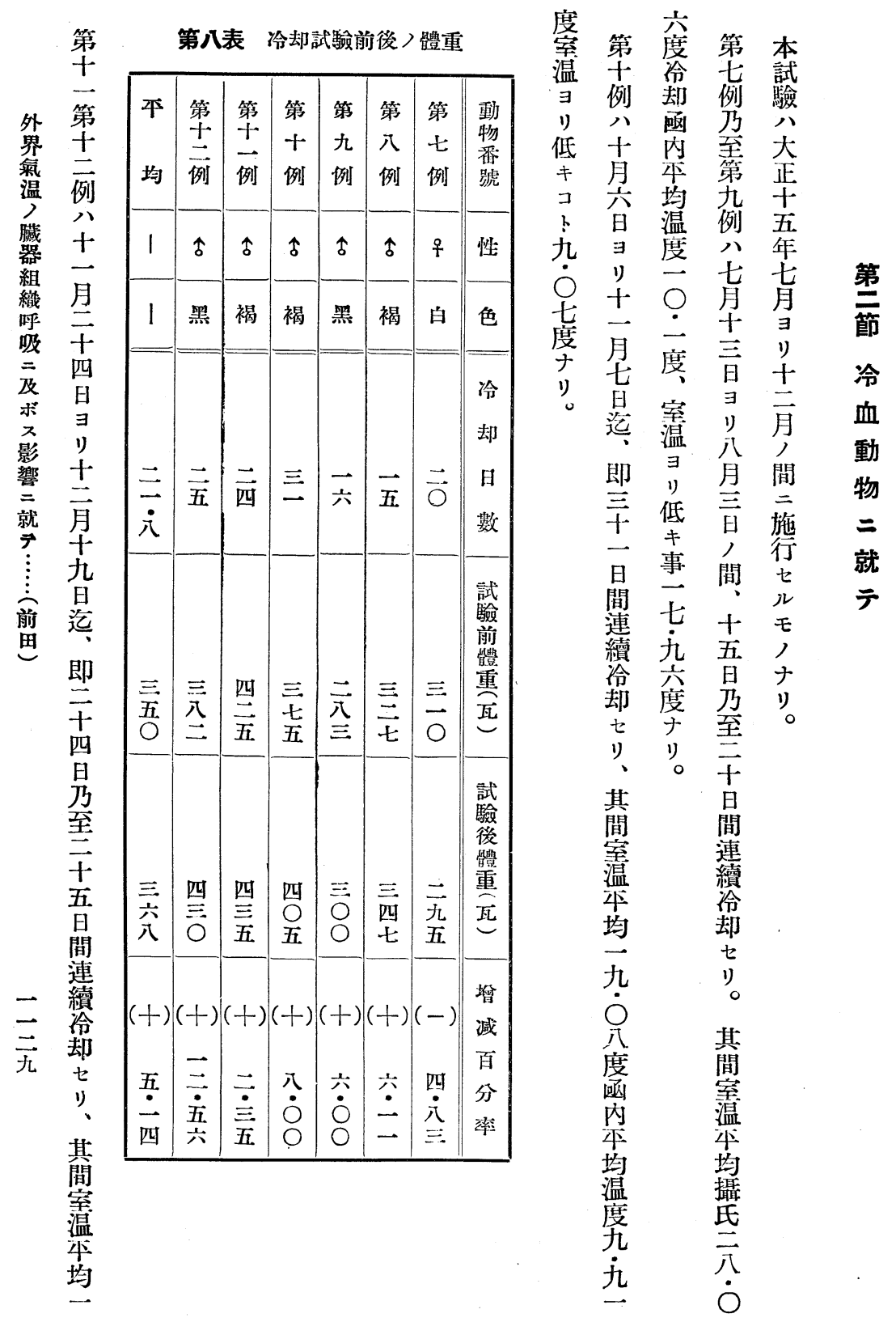



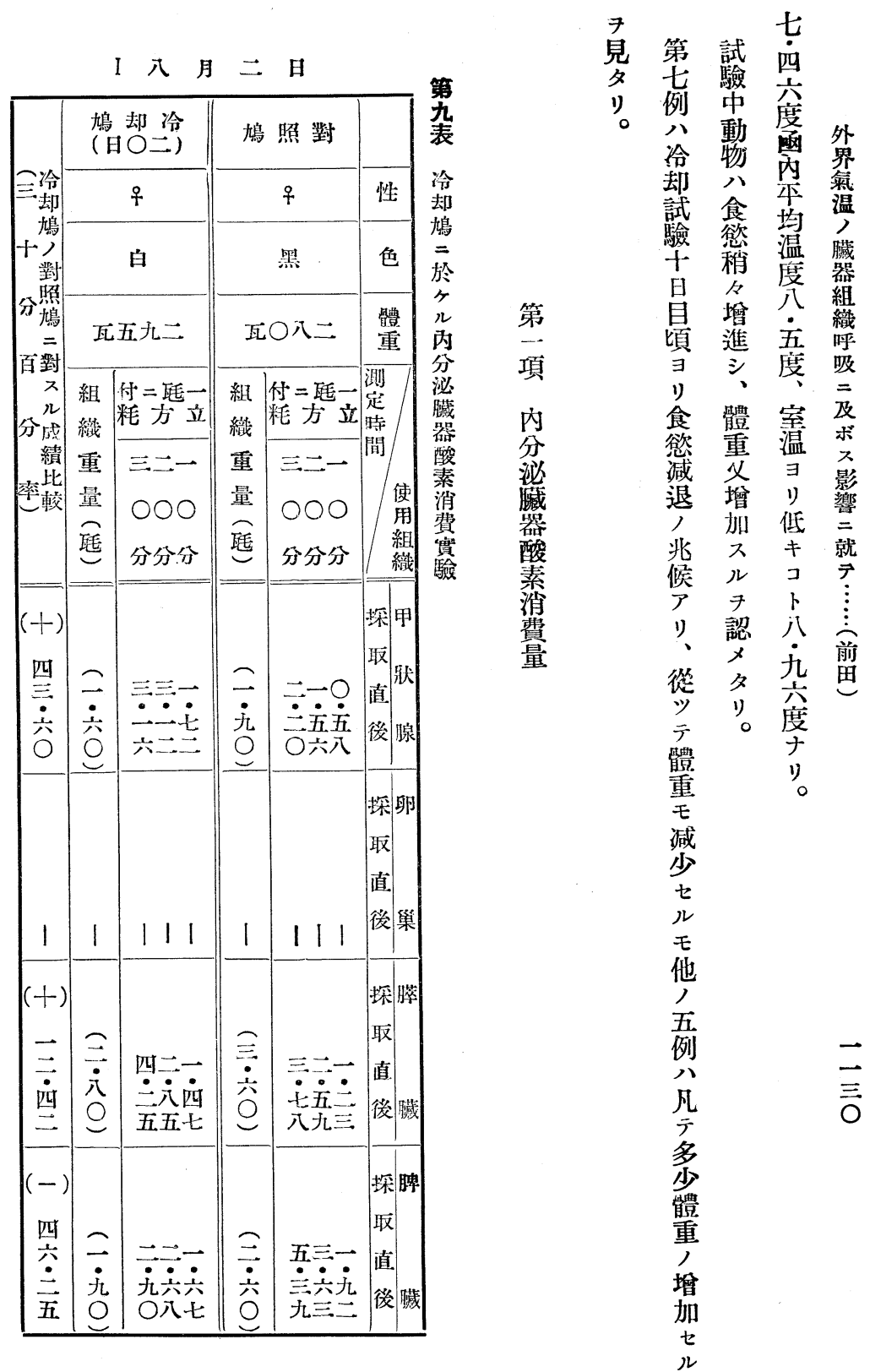


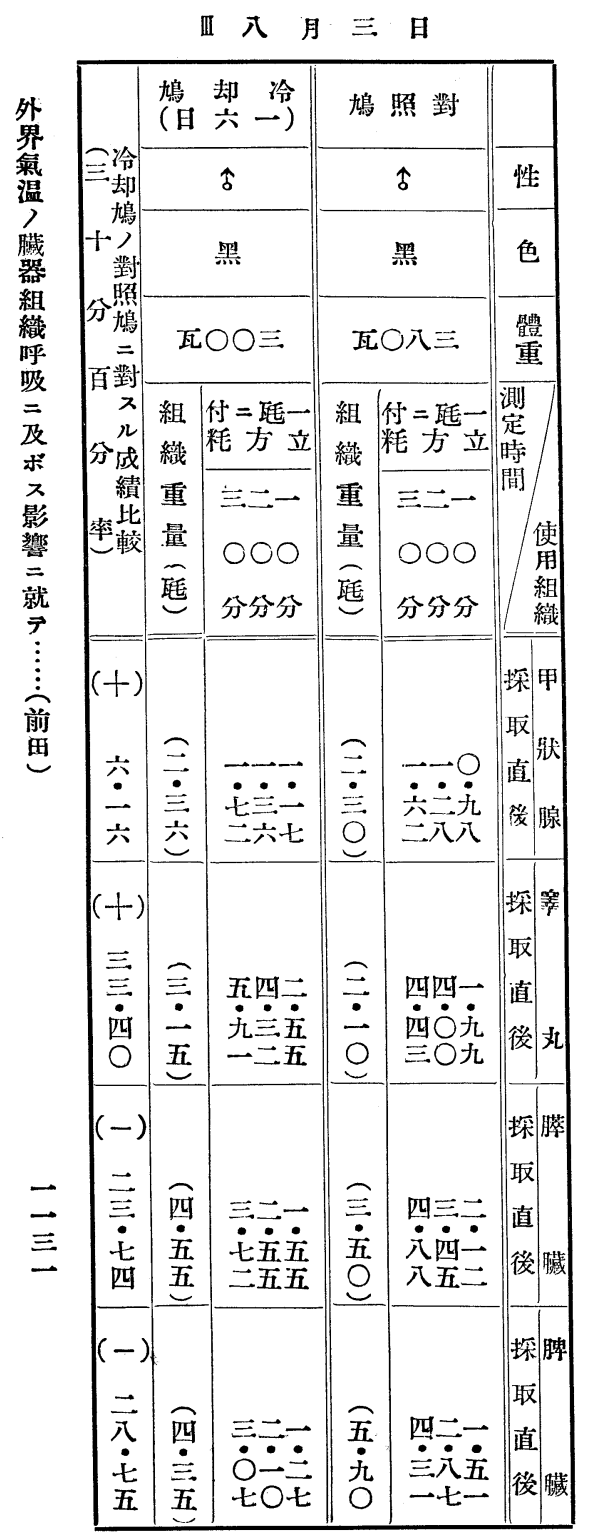

\begin{tabular}{|c|c|c|c|c|c|}
\hline \multirow{8}{*}{ 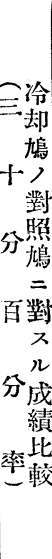 } & \multicolumn{2}{|c|}{ 沜 } & \multicolumn{2}{|c|}{ 沜 照 對 } & \\
\hline & & $\hat{\delta}$ & & \& & 性 \\
\hline & & 褐 & & 黑 & 色 \\
\hline & \multicolumn{2}{|c|}{ 瓦七四三 } & \multicolumn{2}{|c|}{ 瓦五○三 } & $\begin{array}{l}\text { 體 } \\
\text { 重 }\end{array}$ \\
\hline & $\begin{array}{l}\text { 組 } \\
\text { 織 }\end{array}$ & $\begin{array}{l}\text { 付 }=\text { 琵一 } \\
\text { 粍 立 }\end{array}$ & & $\begin{array}{l}\text { 售=琵一 } \\
\text { 方 }\end{array}$ & 浿 \\
\hline & 重 & $\equiv 二-$ & 重 & $\equiv 二-$ & \\
\hline & 量 & 000 & 量 & 000 & 使 \\
\hline & 琶 & 分分分 & 琶 & 分分分 & $\mid \begin{array}{l}\text { 絸 } \\
\text { 織 }\end{array}$ \\
\hline$(+)$ & & & & & \\
\hline$\equiv$ & I & & $\cong$ & & 猒 \\
\hline 忘 & 壳 & $\dot{\mathrm{t}} \dot{\mathrm{O}} \dot{\mathbf{O}}$ & 家 & $\begin{array}{l}\text { 穴五无 } \\
\text { 五七六 }\end{array}$ & 㷋腺 \\
\hline$(+)$ & & & & & 探室 \\
\hline 亲 & 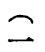 & 八六三 & $\fallingdotseq$ & 五三一 & 直 \\
\hline$\dot{\Xi}$ & $\dot{\nabla \sigma}$ & 分无三 & 六 & 西分无 & 車 \\
\hline 五 & 0 & 一○五 & 五 & $\equiv \equiv$ 四 & \\
\hline$(-)$ & & & & & 部腈 \\
\hline 九 & ఏ & $\equiv \div$ & 四 & $\equiv \div$ & 直 \\
\hline 言 & 旮 & 言公主 & 突 & $\begin{array}{l}\text { 关五四 } \\
\equiv\end{array}$ & 後臟 \\
\hline$(+)$ & & & & & 堔脾 \\
\hline 三 & $=$ & & $\fallingdotseq$ & & \\
\hline i & $\dot{\square}$ & 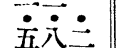 & $\overrightarrow{\nabla 4}$ & $\because \dot{\square}$ & 直 \\
\hline 0 & 0 & 五七七 & 五 & 五五九 & 後欌 \\
\hline
\end{tabular}




\begin{tabular}{|c|c|c|c|c|c|}
\hline \multirow{8}{*}{ 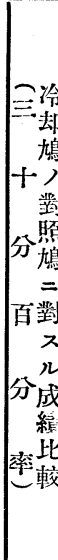 } & \multicolumn{2}{|c|}{$\begin{array}{ll}\text { 鴻 却 } \\
\text { (冷 }\end{array}$} & \multicolumn{2}{|c|}{ 沜 照 對 } & \\
\hline & & f & & 今 & 性 \\
\hline & & 褐 & & 黑 & 色 \\
\hline & \multicolumn{2}{|c|}{ 瓦五三四 } & \multicolumn{2}{|c|}{ 瓦五六二 } & $\begin{array}{l}\text { 體 } \\
\text { 重 }\end{array}$ \\
\hline & & \begin{tabular}{|l|} 
付=烈一 \\
粍方立
\end{tabular} & & $\begin{array}{l}\text { 付=残一 } \\
\text { 祀方立 }\end{array}$ & 测 \\
\hline & 重 & $\equiv$ 三一 & 重 & $\equiv$ 三一 & 間 \\
\hline & 量 & 000 & 量 & 000 & 使 \\
\hline & 琶 & 分分分 & 琶 & 分分分 & $\begin{array}{l}\text { 組 } \\
\text { 織 }\end{array}$ \\
\hline$(+)$ & & & & & 堔电 \\
\hline 三 & 9 & $=-0$ & ב & & $=\pi$ \\
\hline$\doteq$ & $\dot{0}$ & $\dot{0} \dot{\dot{0}} \dot{ }$ & $\therefore$ & $\dot{\bar{\pi}} \dot{-\dot{1}}$ & 国 \\
\hline 六 & 五 & O八t & 0 & 一六○ & 使腺 \\
\hline +) & & & & & 探䍘 \\
\hline$\frac{\text { 四 }}{\pi}$ & $\fallingdotseq$ & $\pi=-1$ & $=$ & & \\
\hline$\because$ & $\dot{\mathrm{i}}$ & $\dot{0} \dot{\dot{t}} \dot{0}$ & 它 & 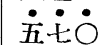 & 相 \\
\hline 0 & 0 & 八二五 & 0 & O九九 & 侄机 \\
\hline$(+)$ & & & & & 深渵 \\
\hline 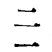 & 元 & & & & 取 \\
\hline$\dot{t}$ & $\dot{t}$ & 六无方 & $\ddot{0}$ & $\ddot{\operatorname{c}} \dot{ } \doteq$ & 遖 \\
\hline$\equiv$ & O & 五三三 & 0 & 二七八 & |後䠞 \\
\hline t) & & & & & 蜉脾 \\
\hline 量 & $t$ & 四二二 & 五 & $\equiv$ 三一 & 直 \\
\hline $\overrightarrow{\overrightarrow{0}}$ & 0 & 分- & 公 & $\dot{0} \dot{0} \dot{二}$ & 後淢 \\
\hline 10 & $t$ & \#.儿t & 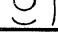 & & \\
\hline
\end{tabular}

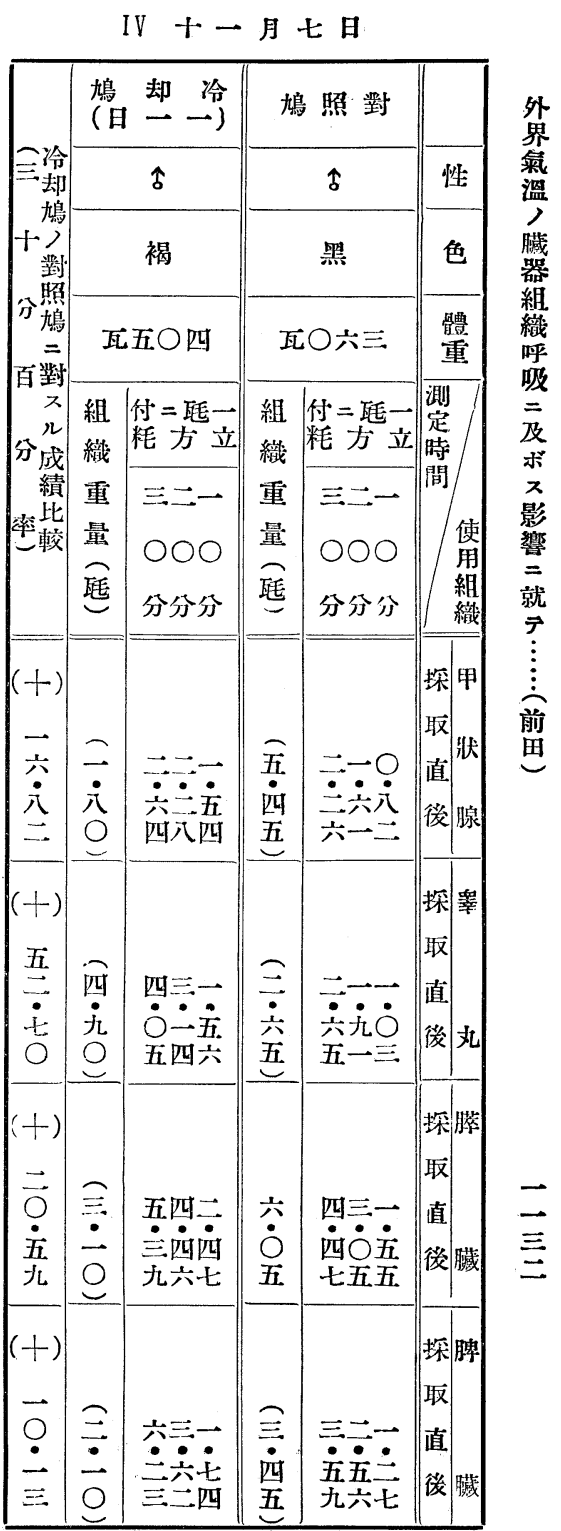


VI十二月十九日
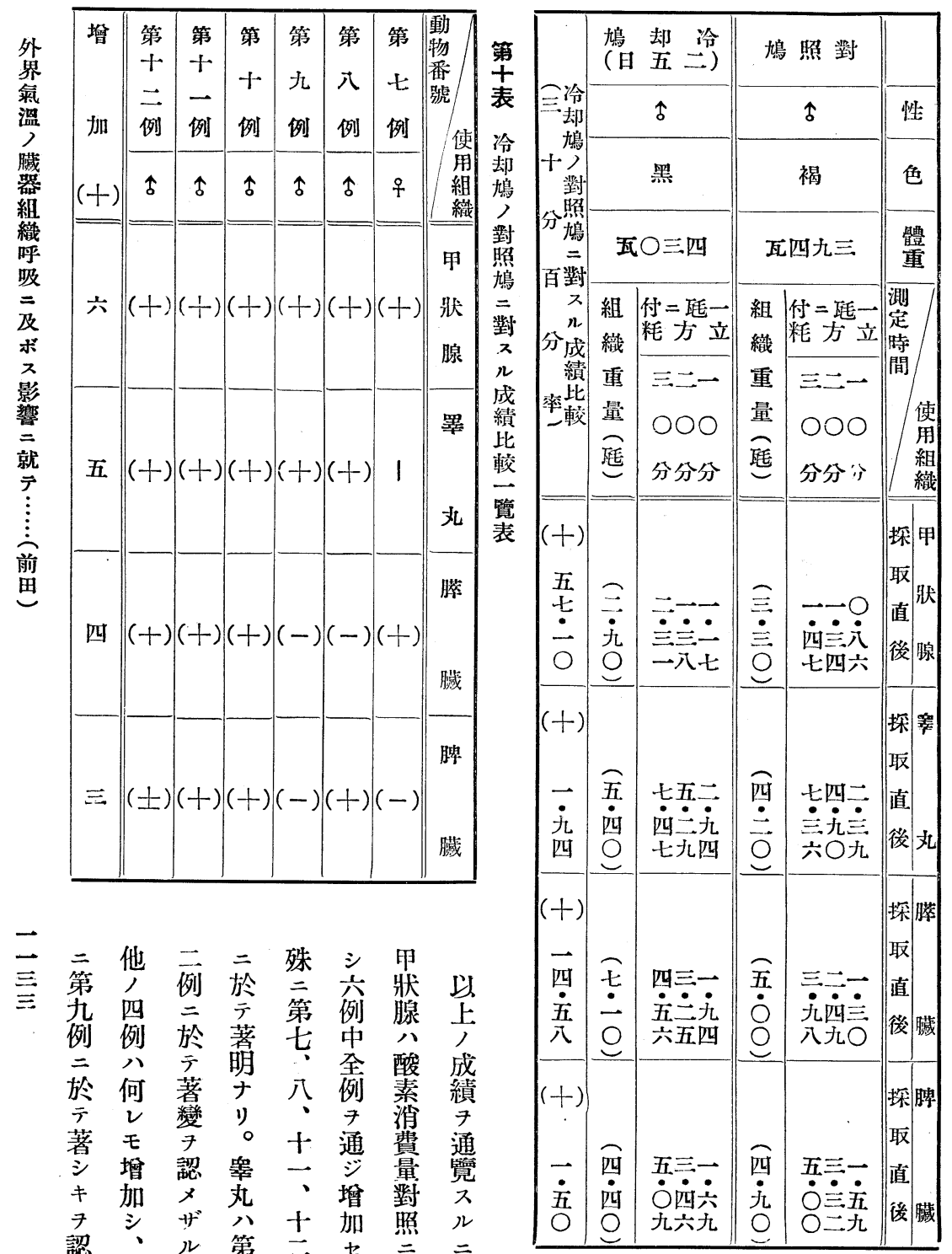

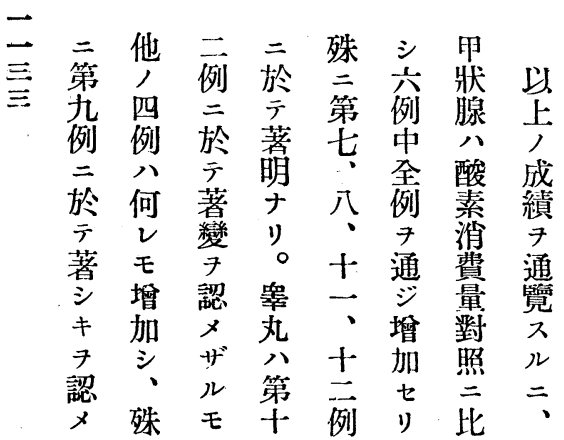




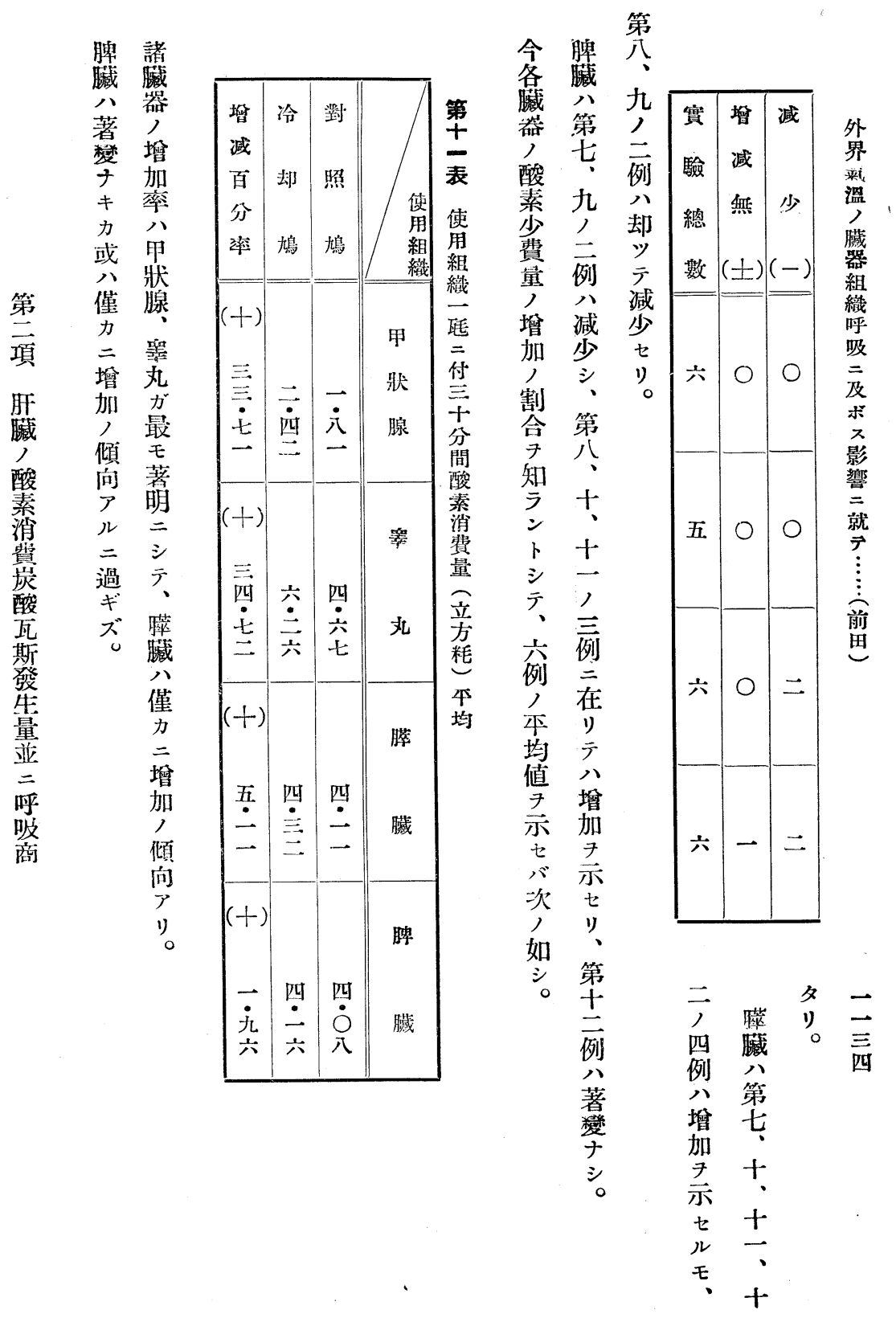



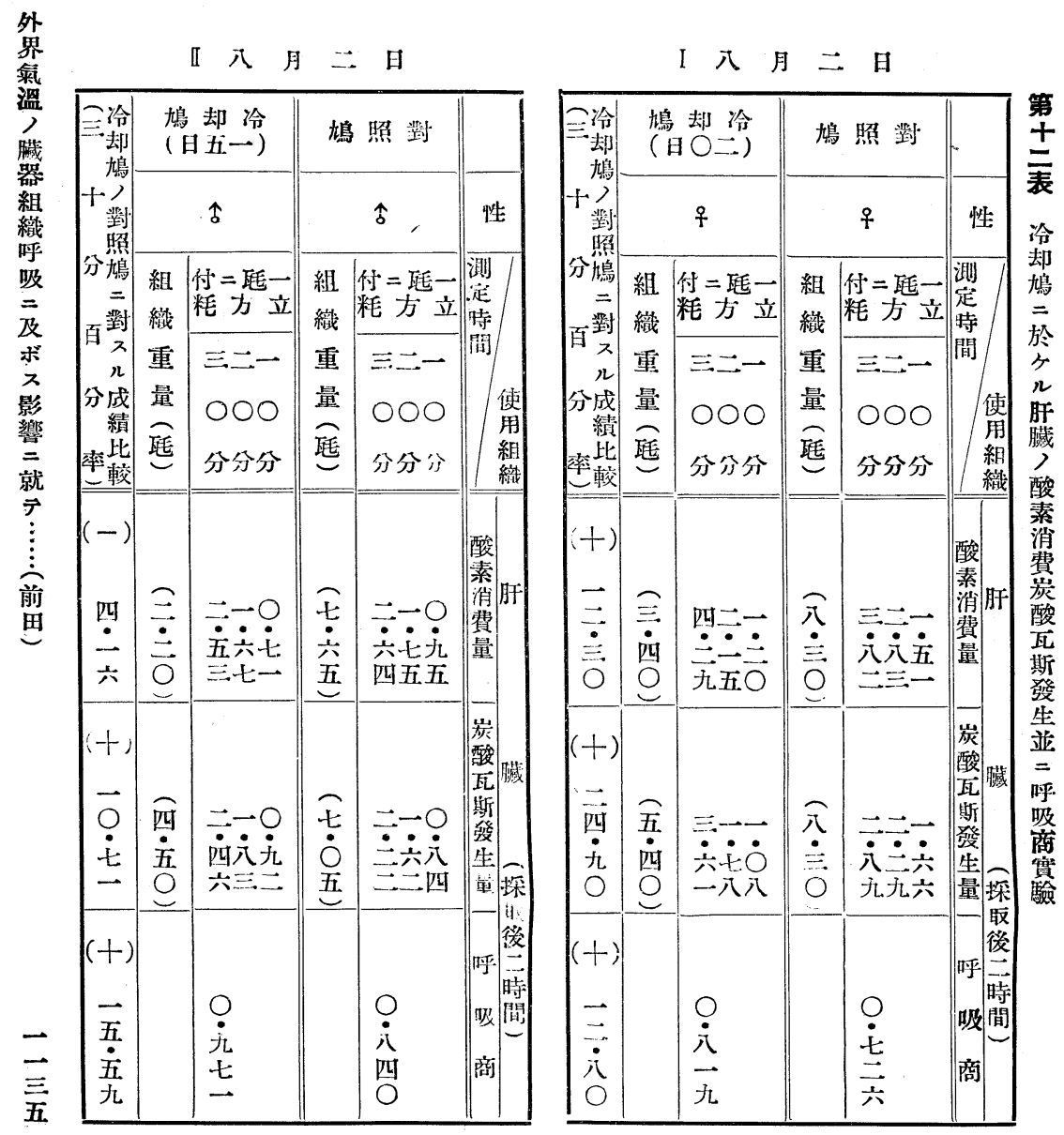
IV十一月七日

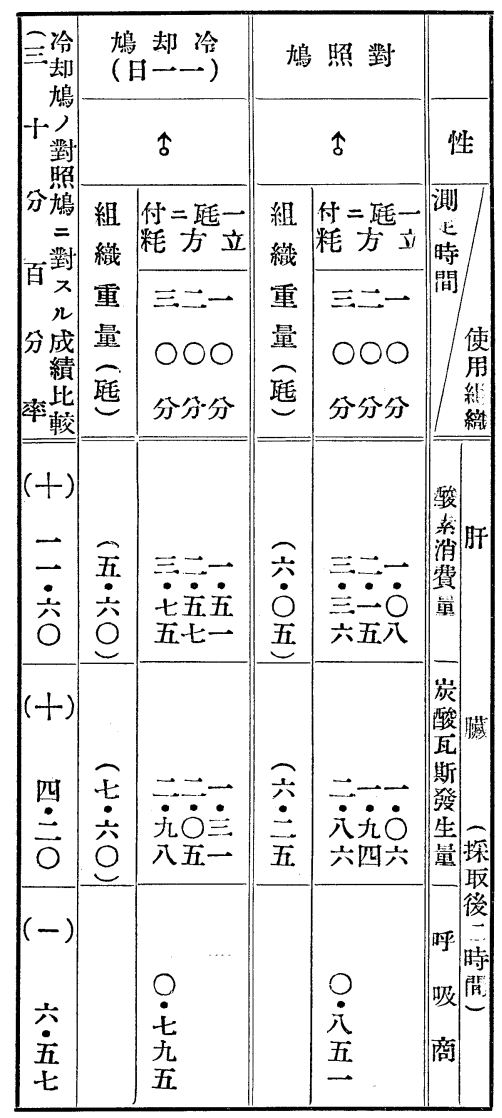

III 八月 日

\begin{tabular}{|c|c|c|c|c|c|}
\hline \multirow{3}{*}{ 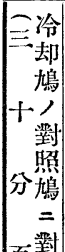 } & \multicolumn{2}{|c|}{$\begin{array}{l}\text { 鳩 却 冷 } \\
(\text { 日六一) }\end{array}$} & \multicolumn{2}{|c|}{ 鳩 照 對 } & \\
\hline & \multicolumn{2}{|r|}{$\hat{\delta}$} & \multicolumn{2}{|r|}{$\uparrow$} & 性 \\
\hline & $\begin{array}{l}\text { 組 } \\
\text { 織 }\end{array}$ & 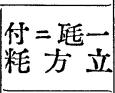 & $\begin{array}{l}\text { 組 } \\
\text { 織 }\end{array}$ & \begin{tabular}{|l} 
付 $=$ 姐一 \\
粍 方
\end{tabular} & 測 \\
\hline$\left|\begin{array}{rr}\theta & \pi \\
\lambda\end{array}\right|$ & 重 & $\equiv$ 二- & 重 & $\equiv$ 二- & 間 \\
\hline 分成 & 量 & 000 & 量 & 000 & 使 \\
\hline 率此 & 㘪 & 分分分 & 琶 & 分分分 & $\begin{array}{l}\text { 組 } \\
\text { 織 }\end{array}$ \\
\hline$=$ & & & & & 酸 \\
\hline 五 & $\equiv$ & $\because \vec{\square}$ & 四 & $\overrightarrow{\overrightarrow{0}}+0$ & 胇" \\
\hline$\equiv$ & 五 & 七五五 & 0 & 六五灻 & \\
\hline+1 & & & & & 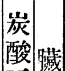 \\
\hline 竎 & $\pi$ & $\equiv \rightarrow-$ & 三 & & 麗 \\
\hline 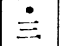 & 六 & 六元无 & $\dot{\text { 九 }}$ & $\dot{\dot{i}} \dot{ }$ & 㢸 \\
\hline 0 & 五 & 二七六 & 0 & $\hat{0}-0$ & 墨探 \\
\hline$(+)$ & & & & & 呼 \\
\hline & & $?$ & & $?$ & 四間 \\
\hline 人 & & $\stackrel{\pi}{\equiv}$ & & t & 商 \\
\hline 六 & & 五 & & 五 & \\
\hline
\end{tabular}




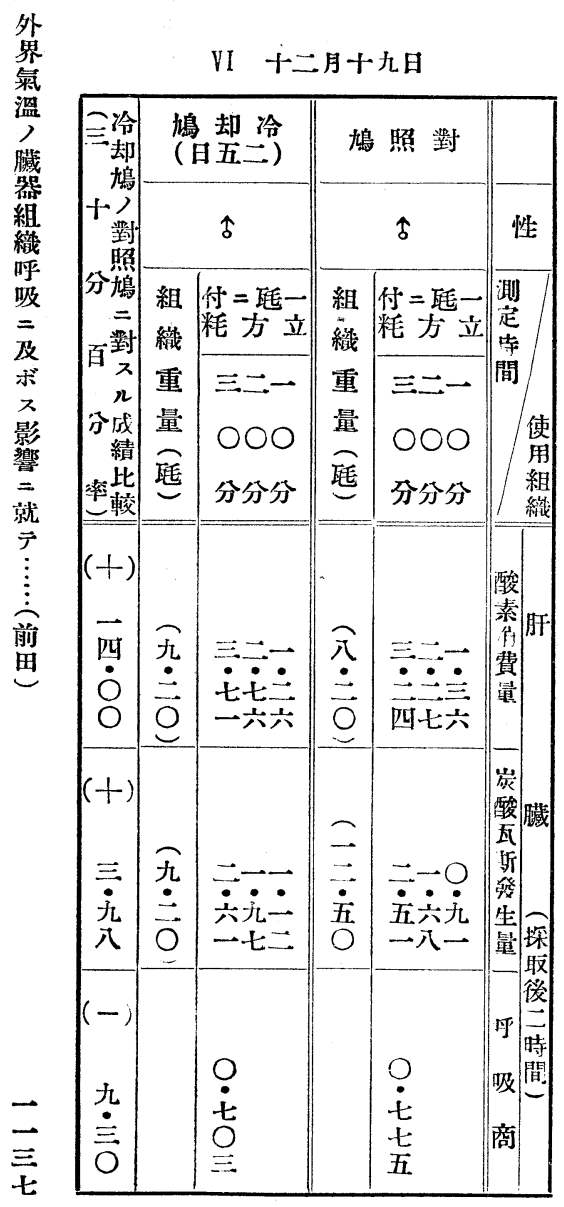

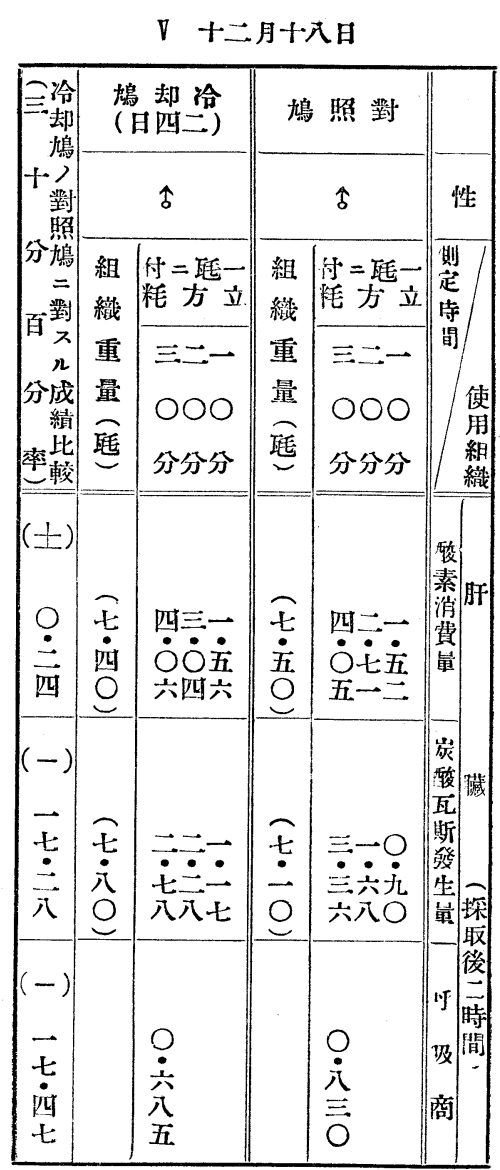


第十三表 冷却鳵〉對照鳵二對スル成績比較一覽表

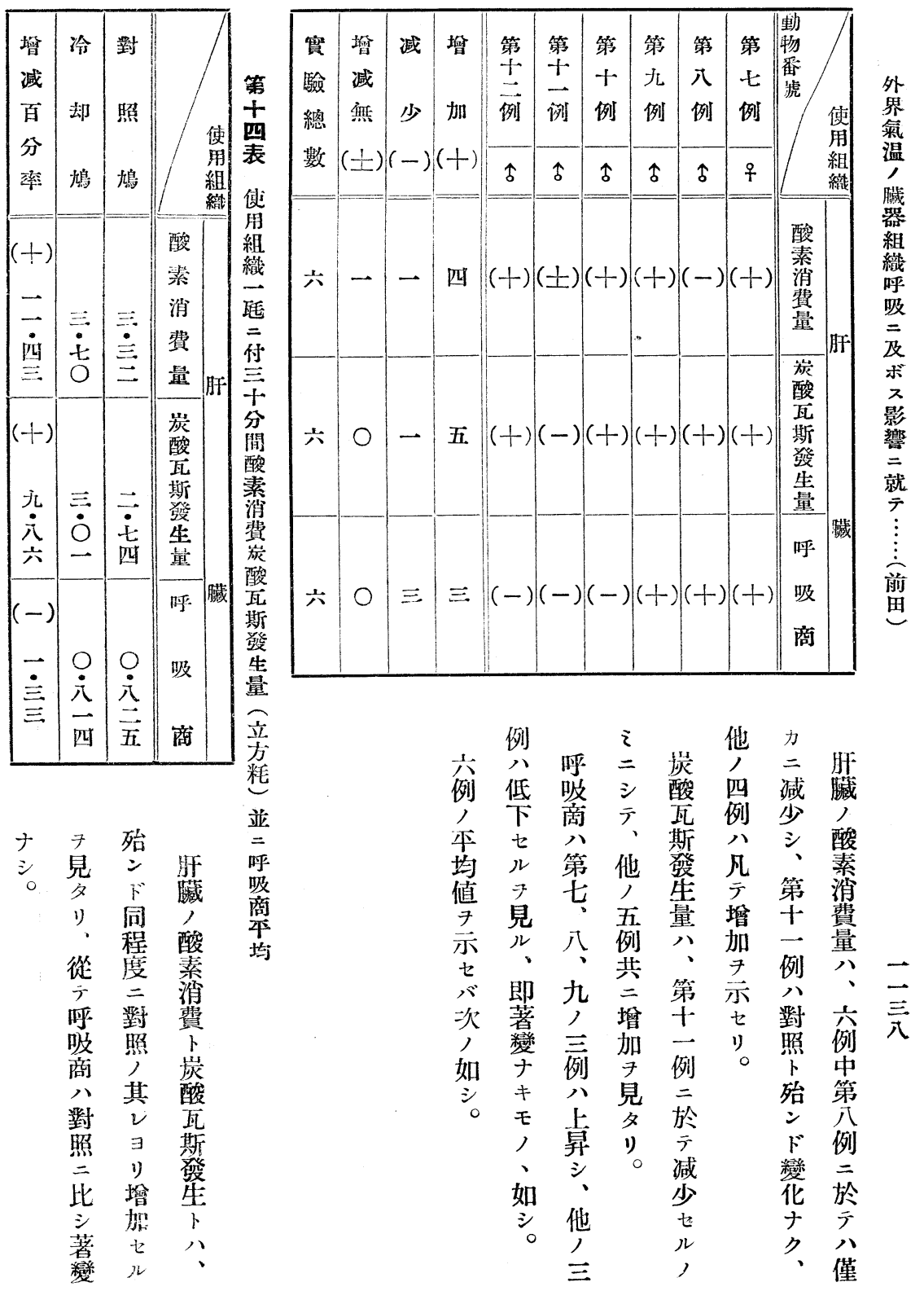




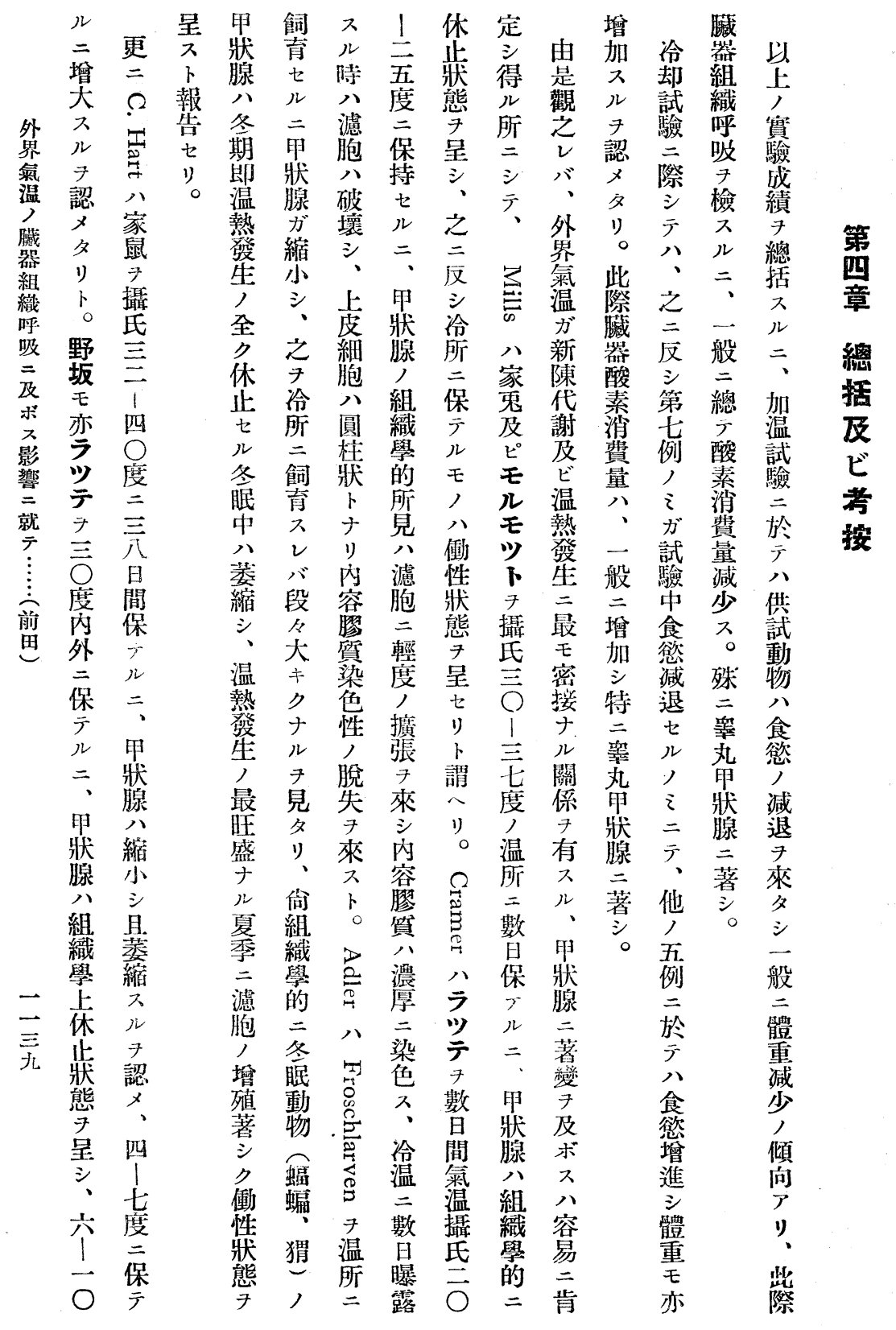




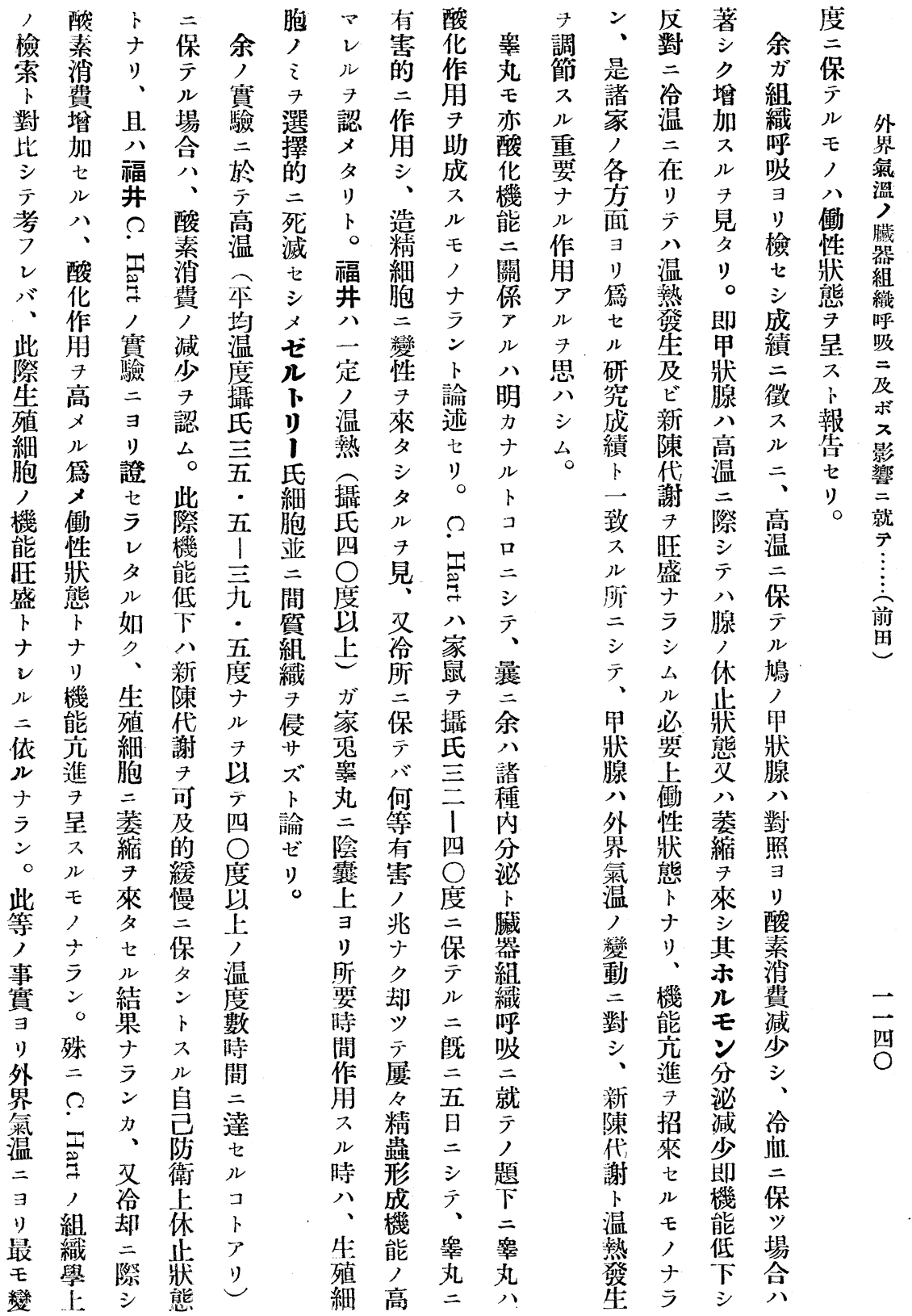




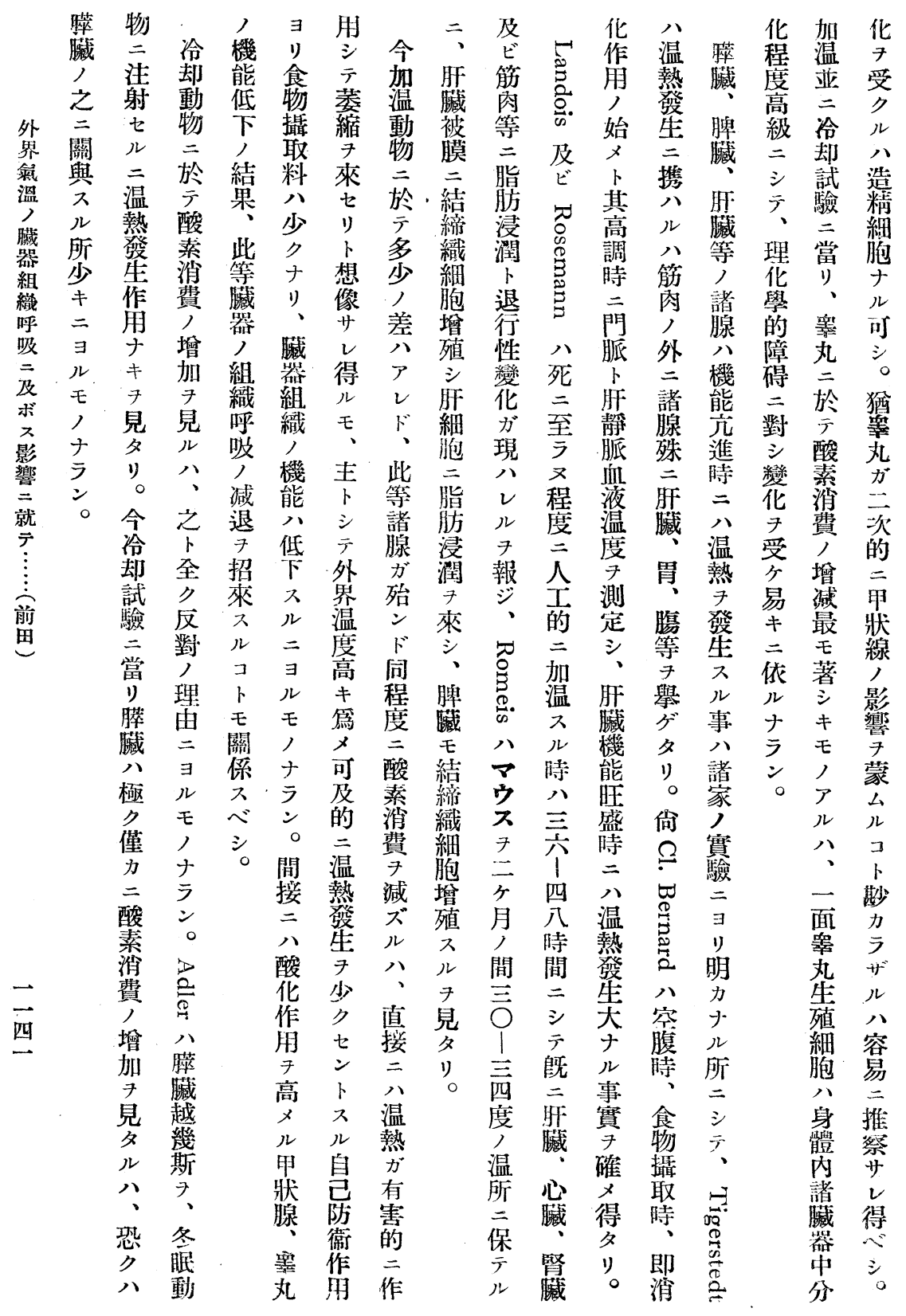




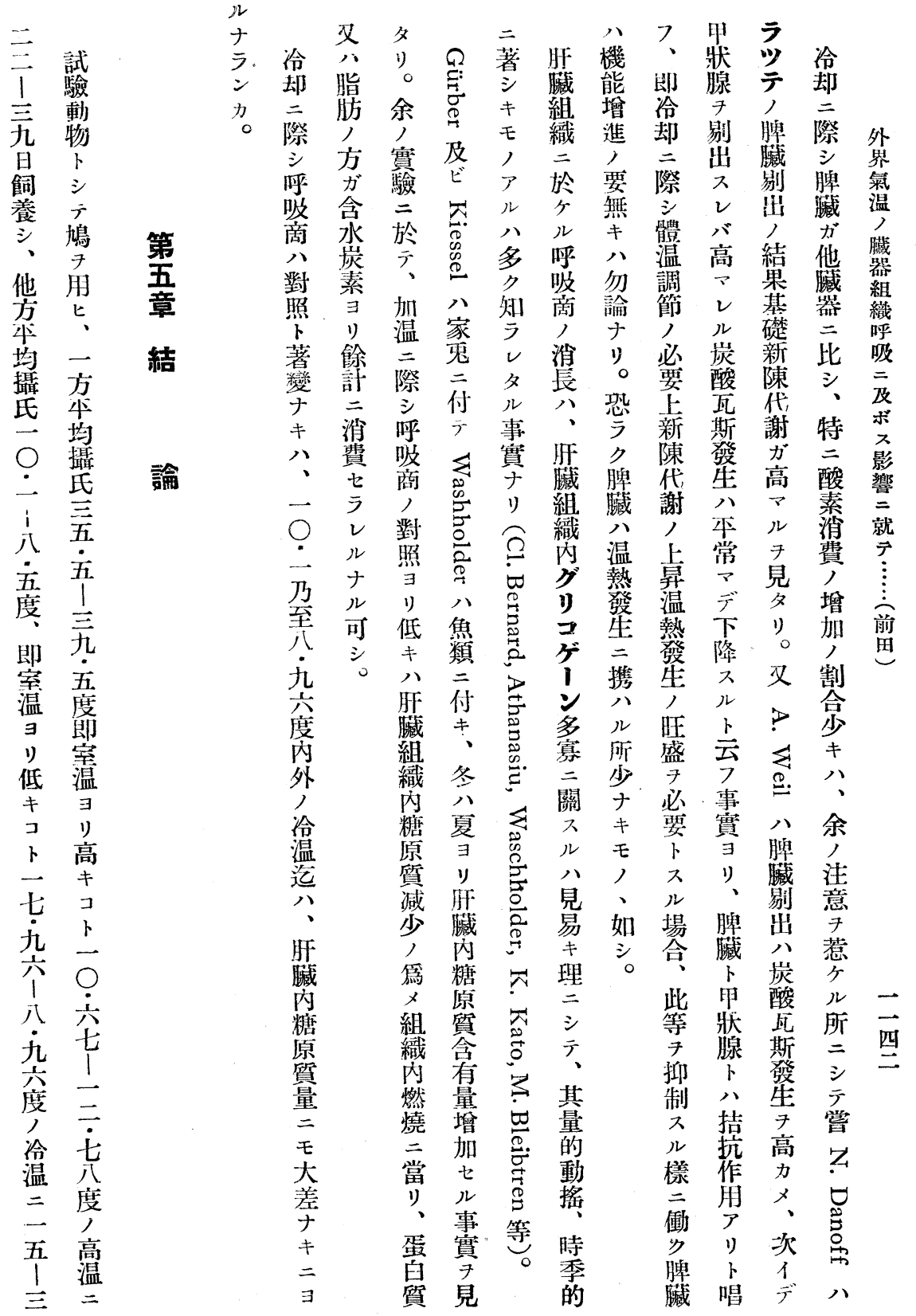



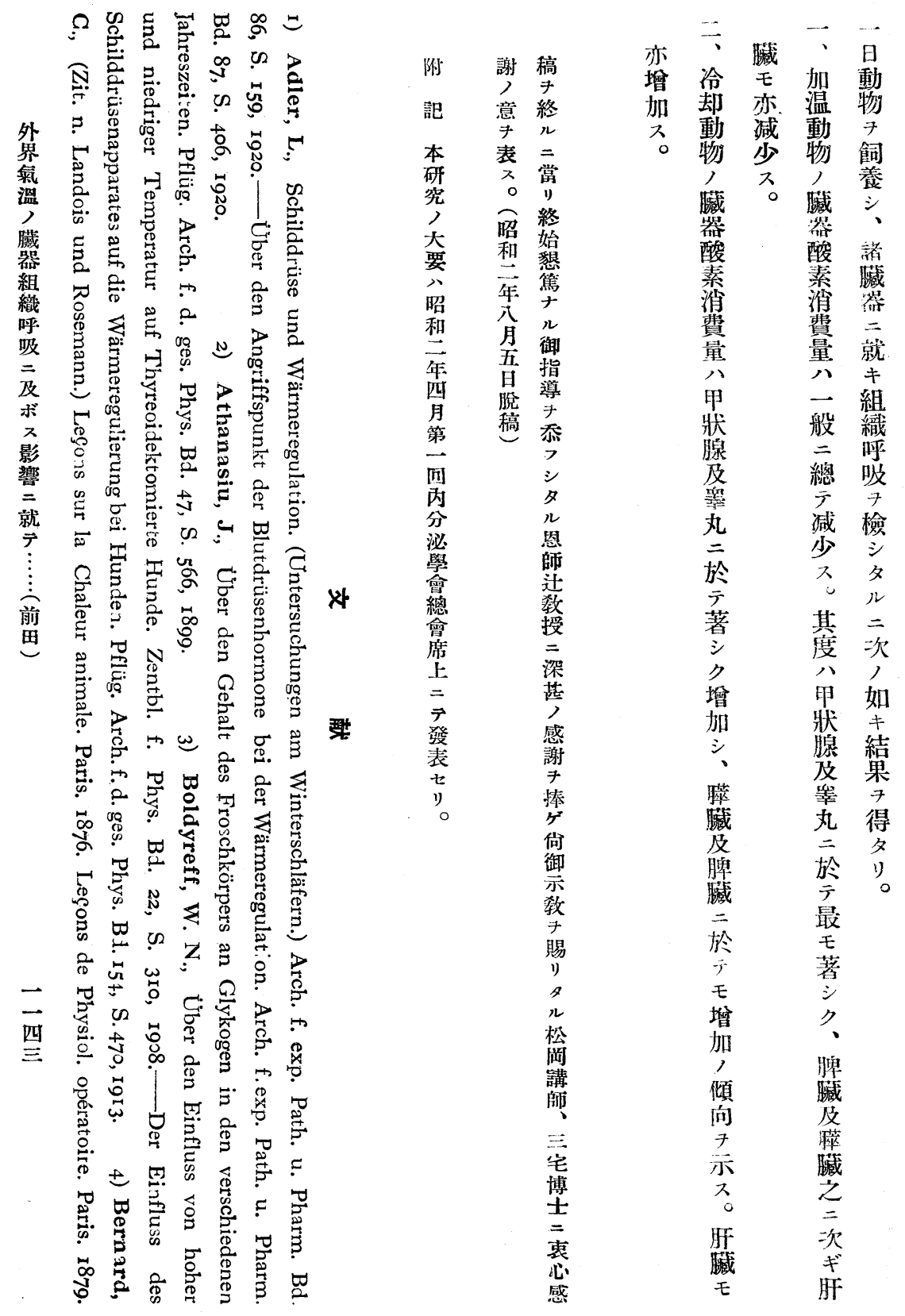


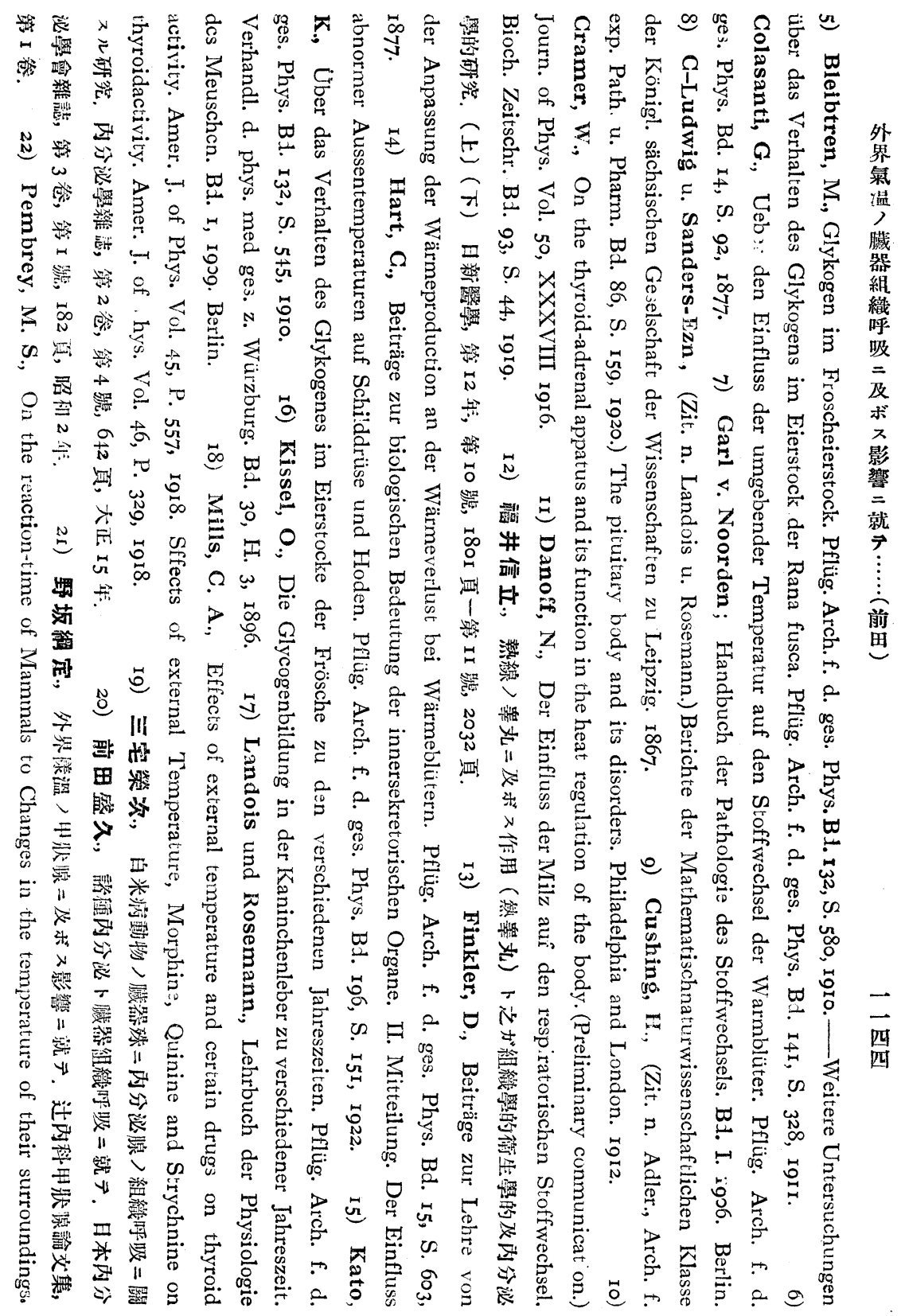



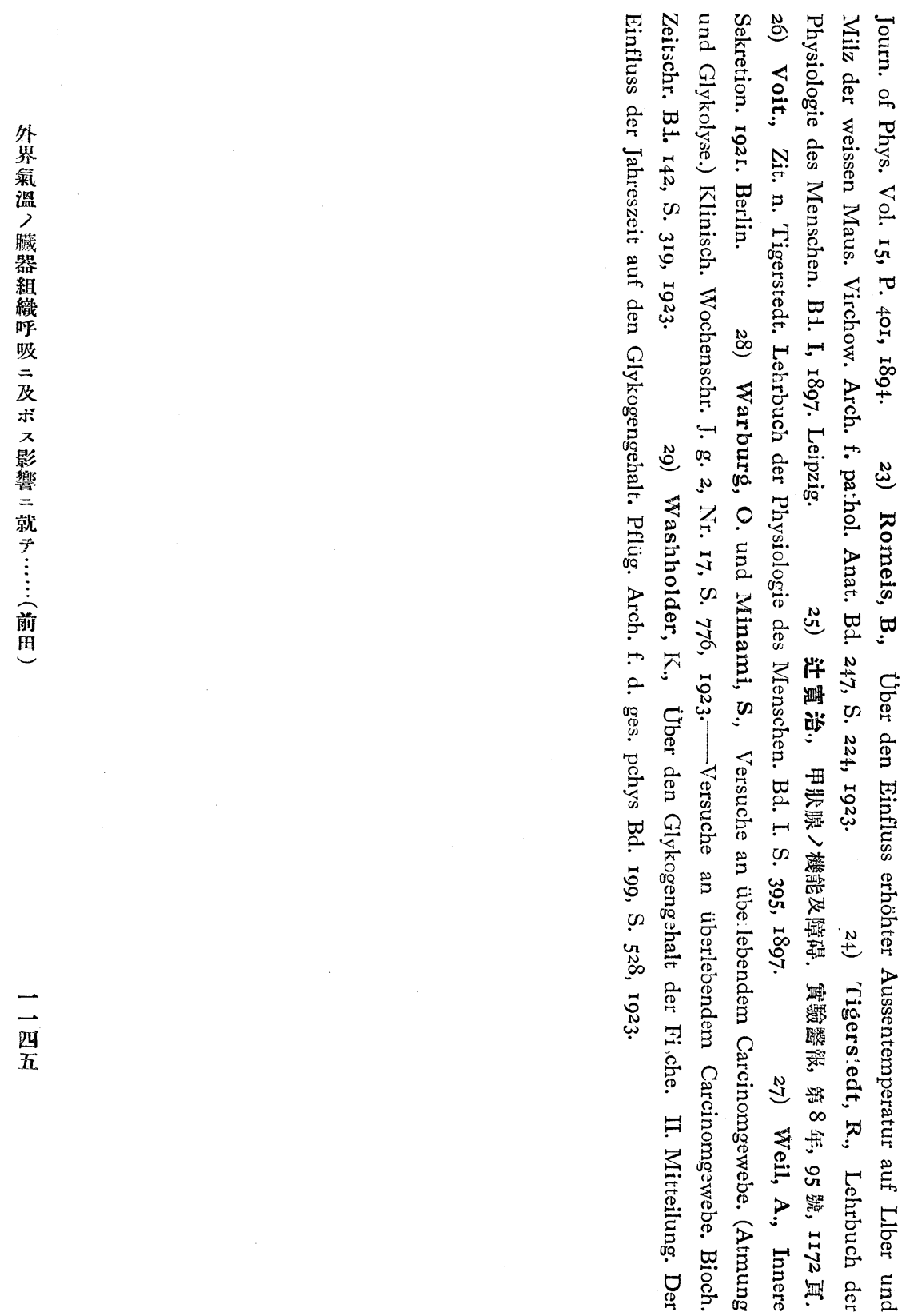
I) Das Gewicht der Schilddrüse war normal. Sie zeigte aber das Bild der Kolloidstruma, nämlich das der Hypofunktion.

2) Die Hypophysis wies Vermehrung des Gewichts auf. Histologisch waren die eosinophjlen Zellen in den Vorderlappen vergrössert und an Zahl vermehrt, und weiter hatte die Kolloidsubstanz im allgemeinen, besonders in den Hinterlappen, zugenommen.

3) Das Gewicht der Bauchspeicheldrüse war etwas vermehrt, und in derselben fand sich Ansammlung des äussersekretorischen Drüsensekrets.

4) Das Gewicht des Hodens war teils vermehrt, teils vermindert und das des Ovariums meistens vermindert, aber die beiden Geschlechtsdrüsen zeigten deutlich das Bild von Atrophie und Degeneration.

5) Die Thymusdrüse und die Nebenniere zeigten keine nennenswerten histologischen Veränderungen.

6) Die oben erwähnten Veränderungen der Hypophysis, des Pankreas und der Geschlechtsdrüsen sind vielleicht sekundärer Natur, wie man sie bei der Hypofunktion der Schilddrüse antrifft.

(Autoreferat.)

\section{UEBER DEN EINFLUSS DER AUSSENTEMPERATUR \\ AUF DIE GEWEBSATMUNG.}

\section{Von}

Dr. M. Maeda.

(Aus der I. med. Klinik der kaiserl. Univers. zu Kyoto, Japan.

Direktor : Prof. Dr. K. Tsuji.)

Mittelst des Barcroftschen Manometers bestimmte der Verfasser die Gewebsatmung verschiedener Organe von Tauben, die bei erhöhter oder erniedrigter Aussentemperatur gehalten wurden. 
Die Ergebnisse lassen sich dahin zusammenfassen:

I. Der Sauerstoffverbrauch der Organe von Tauben, die 23-39 Tage lang einer Aussentemperatur von $35,5-39,5^{\circ} \mathrm{C}$., d. h. einer um ז0,67-12,7 $8^{\circ} \mathrm{C}$. höheren als Zimmertemperatur, ausgesetzt sind, vermindert sich im allgemeinen, u. z. am auffallendsten in Schilddrüse und Hoden, weniger in Milz, Pankreas und Leber.

2. Der Sauerstoffverbrauch von Tauben, die I5 $_{5}-3 \mathrm{I}$ Tage lang bei einer Aussentemperatur von $10,1-8,5^{\circ} \mathrm{C}$, d. h. um $17,96-8,96^{\circ} \mathrm{C}$. niedriger als Zimmertemperatur, gehalten werden, vermehrt sich deutlich in Schilddrüse und Hoden, während Leber, Pankreas und Mliz nur eine garinge Neigung zur Vermehrung zeigen.

(Autoreferat.)

\section{UEBER DEN EINFLUSS DER INNERSEKRETORISCHEN DRÜSEN AUF DEN KOHLENHYDRATSTOFFWECHSEL DER WINTERSCHL $\ddot{A} F E R$.}

\section{Von}

Dr. S. Miyamura.

(Aus der I. med. Klinik d. kaiserl. Univers. zu Kyoto in Japan.

Direktor: Prof. K. Tsuji.)

Der Verfasser gebrauchte als Versuchstier Kröten in der Zeit des Winterschlafes (Bufo vulgaris Japonicus). Nach der Injektion verschiedener innersekretorischer Mittel (Pituitrin, Insulin, Adrenalin) bei kalter Zimmertemperatur $\left(8-5^{\circ} \mathrm{C}\right.$.) und nach der Exstirpation verschiedener innersekretorischer Drüsen (Schilddrüse, Nebennieren, Geschlechtsdrüsen) bei warmer Temperatur $\left(23-20^{\circ} \mathrm{C}\right.$.) bestimmte Verf. chemisch den Leber- und Muskelglykogengehalt und untersuchte mikroskopisch einige innersekretorische Drüsen.

Die Resultate sind die folgenden :-

I) Der Leber- und der Muskelglykogengehalt der im warmen 